\title{
A study of free radical chemistry: their role and pathophysiological significance
}

\author{
Mariusz Gutowski ${ }^{\bowtie}$ and Sławomir Kowalczyk ${ }^{2}$ \\ ${ }^{1}$ Neurovascular Research Laboratory, Faculty of Health, Science and Sport, University of Glamorgan, UK; ${ }^{2}$ Department of Microbiology, Faculty of \\ Pharmacy, Poznan University of Medical Sciences, Poznań, Poland
}

Oxygen is one of the most important molecules on Earth mainly because of the biochemical symmetry of oxygenic photosynthesis and aerobic respiration that can maintain homeostasis within our planet's biosphere. Oxygen can also produce toxic molecules, reactive oxygen species (ROS). ROS play a dual role in biological systems, since they can be either harmful or beneficial to living systems. They can be considered a double-edged sword because at moderate concentrations, nitric oxide (NO), superoxide anion, and related reactive oxygen species play an important role as regulatory mediators in signalling processes. Many of the ROS-mediated responses actually protect the cells against oxidative stress and reestablish "redox homeostasis". On the other hand, overproduction of ROS has the potential to cause damage. In the recent decades, ROS has become a focus of interest in most biomedical disciplines and many types of clinical research. Increasing evidence from research on several diseases shows that oxidative stress is associated with the pathogenesis of diabetes mellitus, obesity, cancer, cardiovascular diseases, inflammation, ischaemia/reperfusion injury, obstructive sleep apnea, neurodegenerative disorders, hypertension and ageing.

Key words: reactive oxygen species, reactive nitrogen species, lipid peroxidation, catalytic ions, ascorbic acid

Received: 19 November, 2012; revised: 10 January, 2013, accepted: 06 March, 2013; available on-line: 19 March, 2013

\section{INTRODUCTION}

This is a good time for a broad overview that summarizes the main principles of redox regulation. We are now living in a particularly exciting time of oxidative stress research where information from different fields and independent approaches is falling into place and beginning to reveal an important portrait. In textbook style, this review describes the current knowledge and paradigms but does not discuss future research directions, historical controversies, or experimental models. Moreover, it was not within the scope of this review to deal with all the details. Even the more than 200 references cited here do not cover all relevant publications in the field.

\section{Historic Background}

The world of free radicals in biological systems was explored in 1956 by D. Harman who proposed the concept of free radicals playing a role in ageing (Harman, 1956). In 1977, Mittal and Murad provided evidence that the hydroxyl radical $(\cdot \mathrm{OH})$ stimulates activation of gua- nylate cyclase and formation of the "second messenger" cyclic guanosine monophosphate (cGMP). Since then, a large body of evidence has accumulated that living systems have not only adapted to a coexistence with free radicals but have developed various mechanisms for the advantageous use of free radicals in various physiological functions. There are several definitions of the term "free radical", as well as debates about whether the term "free" is unnecessary. "Radical" and "free radical" are frequently used interchangeably. Any reactive molecule with an unpaired electron is traditionally represented by the application of a superscript dot $\left(^{\circ}\right)$. Originally, "free" was used by chemists to distinguish between $\mathrm{R}$ " and $\mathrm{R}^{*}-\mathrm{X}^{*}, \mathrm{R}^{*}$ being free "radical" and $\mathrm{R}^{*}$ in $\mathrm{R}^{\cdot}-\mathrm{X}^{*}$ being a bound "radical". We accept a simple definition that a free radical is any atom (e.g., oxygen, nitrogen) or group of atoms or molecular species capable of independent existence that contains at least one or more unpaired electrons in the outermost shell configuration (Halliwell \& Gutteridge, 1989). Free radicals are also known as reactive oxygen species (ROS) or reactive nitrogen species (RNS) (Halliwell \& Gutteridge, 2000). This unpaired electron usually gives a considerable degree of reactivity to the free radical.

\section{MAJOR TYPES OF FREE RADICALS}

\section{Reactive Oxygen Species (ROS)}

The causes of the poisonous properties of oxygen were obscure prior to the publication of Gershman's free radical theory of oxygen toxicity in 1954, which states that the toxicity of oxygen is due to partially reduced forms of oxygen (Gershman et al., 1954). Oxygen-centred free radicals are those in which an unpaired electron is on an oxygen atom and contain two unpaired electrons in the outer shell. When free radicals "steal" an electron from a surrounding compound or molecule a new free radical is formed in its place. In turn, the newly formed radical then looks to return to its ground state by stealing electrons with antiparallel spins from cellular structures or molecules. Thus the chain reaction contin-

e-mail: dr.gutowskimariusz@gmail.com

Abbreviations: ROS, reactive oxygen species; RNS, reactive nitrogen species; $E^{\circ \prime}$, reduction potential; $C G M P$, cyclic guanosine monophosphate; EPR, Electron paramagnetic resonance spectroscopy; $\mathrm{AU}$, arbitrary units; $\mathrm{G}$; $\mathrm{RSNO}$, nitrosothiols; $\mathrm{AH}^{-}$, ascorbate anion; $\mathrm{DHA}$, dehydroascorbic acid; SOD, superoxide dismutase; LPO, lipid peroxidation: PUFAs, polyunsaturated fatty acids; $C D$, conjugated diene; GSH, glutathione; DABCO, 1,4-diazabicyclo[2.2.2]octane; R- alkyl group 
ues and can be "thousands of events long" (Valko et al., 2006).

Radicals derived from oxygen represent the most important class of radical species generated by organisms (Miller \& Aust, 1988). Any free radical involving oxygen can be referred to as reactive oxygen species (ROS). A major consequence of oxidative stress is damage to nucleic acid bases, lipids, and proteins, which can severely compromise cell functioning and viability or induce a variety of cellular responses through generation of secondary reactive species, ultimately leading to cell death by necrosis or apoptosis (Halliwell, 2001; Klaunig \& Kamendulis, 2004; Stocker \& Keaney, 2004). However, definitive evidence for this association has often been lacking because of recognised shortcomings with biomarkers and/or methods available to assess oxidative stress status in humans. Emphasis is now being placed on biomarkers of oxidative stress, which are objectively measured and evaluated as indicators of normal biological and pathogenic processes or pharmacologic responses to therapeutic intervention. "Redox" or oxidation-reduction reactions are those reactions that involve exchange of electrons between molecular species.

One of the most common and important oxygen free radicals is the superoxide anion $\left(\mathrm{O}_{2}{ }^{-}\right)$, which can be dismutated to form hydrogen peroxide $\left(\mathrm{H}_{2} \mathrm{O}_{2}\right)$ and the highly reactive hydroxyl radical $\left({ }^{\circ} \mathrm{OH}\right)$ in the presence of $\mathrm{Fe}^{2+}$ and trace metals (Valko et al., 2005). At high concentrations, ROS can be important mediators of damage to cell structures, nucleic acids, lipids and proteins (Valko et al., 2006). Excessive generation of ROS may lead to stimulation of inflammatory process, secretion of chemotactic factors, growth factors, proteolytic enzymes, lipoxygenases, and cyclooxygenases, inactivation of antiproteolytic enzymes and activation of oncogenes and transcription factors (Kehrer, 1993; Jamieson, 1989). It is well established that oxygen free radicals and their metabolites can induce direct cell injury, which may activate a cascade of radical reactions promoting the disease. Permanent modification of genetic material resulting from these oxidative damage incidents represents the first step involved in mutagenesis, carcinogenesis and ageing (Dalle-Donne et al., 2006; Jenner 2003; Sayre et al., 2001; Santos et al., 2005; Wang et al., 1996). In the study of age-related increases in concentrations of oxidised biomolecules, disparities have been observed between intracellular and extracellular proteins. The concentrations of oxidative markers were found to increase with age in extracellular proteins more than in intracellular proteins (Linton et al., 2001). This disparity might be explained by a difference in turnover between extracellular (hours to days) and intracellular proteins (minutes to hours). The difference in homeostatic control between extra- and intracellular proteins might also play a role. ROS-derived radicals operate at low but measurable concentrations in the cells. Their "steady-state" concentrations are determined by the balance between their rates of production and removal by various antioxidants.

The various roles of enzymatic antioxidants (SOD, catalase, glutathione peroxidase) and non-enzymatic antioxidants (vitamins $\mathrm{C}$ and $\mathrm{E}$, carotenoids, lipoic acid and others) in the protection against oxidative stress can be found in numerous papers (Catani et al., 2001; Hirota et al., 1999; Miller et al., 2005; Sharoni et al., 2004). Oxidative stress-induced peroxidation of membrane lipids can be very damaging because it leads to alterations in the biological properties of the membrane, such as the degree of fluidity, and can lead to inactivation of membrane-bound receptors or enzymes, which in turn may impair normal cellular function and increase tissue permeability (Bailey et al., 2003). Products of lipid peroxidation such as malondialdehyde (MDA), 4-hydroxy2-nonenal (HNE), 2-propenal (acrolein) and isoprostanes are commonly used as biomarkers of oxidative damage (Cracowski et al., 2002; Montuschi et al., 2004). Proteins are major targets for ROS because of their high overall abundance in biological systems. Since proteins are primarily responsible for most of cell activities, their peroxidative damage by ROS is of particular importance. It has been estimated that proteins can scavenge the majority $(50 \%-75 \%)$ of reactive species generated (Davies et al., 1999). Exposure of proteins to ROS may alter every level of protein structure from primary to quaternary (if multimeric proteins), causing major physical changes in protein structure. Oxidative damage to proteins is induced either directly by ROS or indirectly by reaction of secondary by-products of oxidative stress and can occur via different mechanisms leading to peptide backbone cleavage, cross-linking and/or modification of the side chain of virtually any amino acid (Dean et al., 1997; Stadtman \& Berlett, 1997). Several mechanism in vivo produce $\mathrm{ROS}$. $\mathrm{O}_{2}{ }^{--}$results from mitochondrial electron transport chain leakage, ischaemia-reperfusion, autooxidation reactions, respiratory burst involving phagocitic cells, and continuous production of $\mathrm{O}_{2}{ }^{-}$by the vascular endothelium to neutralise nitric oxide (NO*) (Young \& Woodside, 2001).

The primary mechanism of $\mathrm{O}_{2}{ }^{--}$production during exercise appears to be from mitochondria. $\mathrm{H}_{2} \mathrm{O}_{2}$ is produced by a variety of intracellular reactions, although the predominant pathway is by dismutation of $\mathrm{O}_{2}{ }^{--}$by the enzyme superoxide dismutase (SOD) (McCord \& Fridovich, 1988; Halliwell, 1999). By far the most widely known mechanism of formation in vivo of the extremely pernicious ${ }^{\circ} \mathrm{OH}$ is the transition metal-catalysed (Fenton chemistry) decomposition of $\mathrm{O}_{2}{ }^{--}$and $\mathrm{H}_{2} \mathrm{O}_{2}$. Within vascular endothelial cells the primary site of ROS generation is the electron transport chain of mitochondria. Although most of molecular oxygen is reduced at complex IV to water, $1-4 \%$ of the oxygen is incompletely reduced to $\mathrm{O}_{2}^{\cdot-}$, which can yield other ROS via numerous enzymatic or non-enzymatic reactions (Zhang \& Gutterman, 2007).

\section{Superoxide anion $\left(\mathrm{O}_{2}^{--}\right)$}

Molecular oxygen has a unique electronic configuration and is itself a di-radical with two such unpaired electrons (Miller et al., 1990). If a single electron is added to the ground-state $\mathrm{O}_{2}$ molecule, it must enter one of the $\pi$ antibonding orbitals. The product is called superoxide anion $\left(\mathrm{O}_{2}^{-}\right)$and the production of $\mathrm{O}_{2}{ }^{-}$occurs mostly within the mitochondria (electron transport chain) of a cell (Halliwell \& Gutteridge, 1989; Cadenas \& Sies, 1998). Physiological concentrations of $\mathrm{O}_{2}{ }^{--}$approach $10 \mu \mathrm{M}$ (Cuzzocrea et al., 2001) and, compared with other free radicals, $\mathrm{O}_{2}{ }^{-}$has a relatively long half-life (Benton et al., 1976) that enables diffusion within the cell thereby increasing the number of potential targets. Beside $\mathrm{O}_{2}{ }^{-}$, other biologically relevant free radicals derived from oxygen are the perhydroxyl radical (protonated superoxide, $\left.\mathrm{HO}_{2}{ }^{-}\right)$, the hydroxyl radical $\left({ }^{\circ} \mathrm{OH}\right)$, and free radical nitric oxide $\left(\mathrm{NO}^{\circ}\right)$. With only one unpaired electron, superoxide is less of a radical than is $\mathrm{O}_{2}$ itself, despite its "super" name. $\mathrm{O}_{2}{ }^{-}$, arising either through metabolic processes or following oxygen activation by physical irradiation, is considered the primary ROS and can further interact with other molecules to generate secondary ROS such 
as lipid radicals, either directly or prevalently through enzyme or metal-catalysed processes (Valko et al., 2005). As a redox-active species, $\mathrm{O}_{2}{ }^{--}$can reduce some biological materials (e.g., cytochrome $c$ ) and oxidise others such as ascorbate. During energy transduction, a small number of electrons "leak" to oxygen prematurely, forming the oxygen free radical $\mathrm{O}_{2}{ }^{-}$(Valko et al., 2004; Kovacic et al., 2005). Complex I can produce $\mathrm{O}_{2}{ }^{-}$as well as hydrogen peroxide $\left(\mathrm{H}_{2} \mathrm{O}_{2}\right)$ through at least two different pathways. During forward electron transfer and during reverse electron transfer only very small amounts of $\mathrm{O}_{2}{ }^{-}$ are produced, less than $0.1 \%$ of the overall electron flow (Murphy, 2009; Hansford et al., 1997). Complex I might be the most important site of $\mathrm{O}_{2}{ }^{--}$production within mitochondria, with up to $5 \%$ of electrons being diverted to superoxide formation (Muller et al., 2008). Measurements on submitochondrial particles suggest an upper limit of $1-3 \%$ of all electrons in the transport chain "leaking" to generate $\mathrm{O}_{2}{ }^{-}$instead of contributing to the reduction of oxygen to water (Boh et al., 1982). $\mathrm{O}_{2}^{--}$is produced from both complexes I and III of the electron transport chain and once in its anionic form it is too strongly charged to readily cross the inner mitochondrial membrane. These two complexes are the main sites of mitochondrial $\mathrm{O}_{2}{ }^{-}$ production (Barja, 1999; Muller et al., 2004).

Recently it has been demonstrated that complex Idependent $\mathrm{O}_{2}{ }^{-}$is exclusively released into the matrix and no detectable levels escape from intact mitochondria (Muller et al., 2004). This finding fits well with the proposed site of the electron leak at complex I, namely the iron-sulphur clusters of the hydrophilic arm. In addition, experiments on complex III show direct extramitochondrial release of $\mathrm{O}_{2}^{--}$but measurements of hydrogen peroxide $\left(\mathrm{H}_{2} \mathrm{O}_{2}\right)$ production have revealed that this could only account for less than $50 \%$ of the total electron leak even in mitochondria lacking $\mathrm{CuZn-SOD.} \mathrm{It} \mathrm{has} \mathrm{been}$ proposed that the remaining $50 \%$ of the electron leak must be due to superoxide released to the matrix (Valko et al., 2007). $\mathrm{O}_{2}{ }^{--}$, in comparison with ${ }^{\circ} \mathrm{OH}$, is far less reactive with non-radical species in aqueous solution. It does react quickly, however, with some other radicals, such as $\mathrm{NO}^{*}$ or phenoxyl radicals formed by abstracting hydrogen from the $-\mathrm{OH}$ group of the amino acid tyrosine $\left(k=1.5 \times 10^{9} \mathrm{M}^{-1} \mathrm{~s}^{-1}\right) \quad(\mathrm{Nagy}$ et al., 2009). The reactivity of $\mathrm{O}_{2}{ }^{-}$with non-radicals varies depending on whether studies are carried out in organic solvents or in aqueous solution and $\mathrm{pH}$ is also an important determinant (Buettner \& Jurkiewicz, 1993).

One of the most popular theories to explain $\mathrm{O}_{2}$ toxicity has been the Gerschman's free radical theory of oxygen toxicity named the Superoxide Theory of $\mathrm{O}_{2}$ Toxicity (Gershman et al., 1954), which states that the toxicity of oxygen is due to partially reduced forms of oxygen and due to over-production of $\mathrm{O}_{2}^{--}$by components such as enzymes, auto-oxidation, haem proteins, mitochondrial electron transport, endoplasmic reticulum or bacteria (e.g., Escherichia coli).

$\mathrm{O}_{2}{ }^{--}$in aqueous solution can act as a reducing agent, i.e. a donor of electrons, for example, it reduces the haem protein cytochrome $c$ (Harel et al., 1988);

cyt $c\left(\mathrm{Fe}^{3+}+\mathrm{O}_{2}{ }^{-} \rightarrow \mathrm{O}_{2}+\right.$ cyt $c\left(\mathrm{Fe}^{2+}\right)$

$\mathrm{O}_{2}^{-{ }^{-}}$can also act as an oxidising agent, e.g., it can oxidise ascorbate (Nishikimi, 1975; Fesseden \& Verma, 1978);

$\mathrm{AH}_{2}+\mathrm{O}_{2}^{\cdot-} \rightarrow \mathrm{A}^{\cdot-}+\mathrm{H}_{2} \mathrm{O}_{2} k=2.7 \times 10^{5} \mathrm{M}^{-1} \mathrm{~s}^{-1}$ at $25^{\circ} \mathrm{C}$ $\mathrm{pH}=7.4$
$\mathrm{O}_{2}{ }^{--}$does not oxidise NAPH or NADH at measurable rates. However, it can interact with NADH bound to the active site of the enzyme lactate dehydrogenase to form an NAD• radical (Petrat et al., 2005);

enzyme-NADH $+\mathrm{O}_{2}^{--}+\mathrm{H}^{+} \rightarrow$ enzyme-NAD $+\mathrm{H}_{2} \mathrm{O}_{2}$

In summary, the tissue toxicity of $\mathrm{O}_{2}^{--}$generated extracellularly seems to be based on its direct reactivity with numerous types of biological molecules (lipid, DNA, RNA, catecholamines, steroids, etc.) and from its dismutation to form $\mathrm{H}_{2} \mathrm{O}_{2}$ and the concomitant reduction of ferric ion $\left(\mathrm{Fe}^{3+}\right)$ to ferrous ion $\left(\mathrm{Fe}^{2+}\right)$; reaction of these two products yields the highly toxic hydroxyl radical that may cleave covalent bonds in proteins and carbohydrates, cause lipid peroxidation, and destroy cell membranes. There are three strategies available to "detoxify" or to prevent formation of locally produced oxygen radicals:

- to deliver SOD (superoxide dismutase) or an SODm (superoxide dismutase mimetic) to the area

- to deliver catalase or a related peroxide scavenger or - to chelate the trace iron that catalyses the reaction.

\section{Hydroxyl radical $(\cdot \mathrm{OH})$}

- $\mathrm{OH}$ is the neutral form of the hydroxide ion. It is short-lived $\left(\sim 10^{-9} \mathrm{~s}\right)$ (Pryor, 1966; Pastor et al., 2000) but reacts very rapidly with almost every type of molecule found in living cells: sugars, amino acids, phospholipids, DNA, and organic acids. Indeed, ${ }^{\circ} \mathrm{OH}$ is the most reactive oxygen radical known, with a highly positive reduction potential of $+2310 \mathrm{mV}$ (Koppenol \& Butler, 1985; Buettner \& Jurkiewicz, 1993; Frelon et al., 2003; Jezowska-Bojczuk et al., 2002; Vergely et al., 2003). 'OH can be generated in biologically relevant systems by multiple reactions including:

Fenton chemistry (the interaction of copper or iron)

$\mathrm{Fe}^{2+}+\mathrm{H}_{2} \mathrm{O}_{2} \mathrm{Fe}^{3+}+\cdot \mathrm{OH}+\mathrm{HO}^{-}$

Haber-Weiss reaction (free radical formed from $\mathrm{O}_{2}{ }^{-}$and $\mathrm{H}_{2} \mathrm{O}_{2}$ )

$\mathrm{O}_{2}^{-}+\mathrm{H}_{2} \mathrm{O}_{2} \cdot \mathrm{OH}+\mathrm{O}_{2}+\mathrm{HO}^{-}$

The Haber-Weiss reaction (Haber \& Weiss, 1932) might provide a means to generate more toxic radicals. Although the basic reaction has a second order rate constant of zero in aqueous solution and thus it cannot take place under physiological conditions, the ability of iron salts to serve as catalysts was discussed by those authors. Because transition metal ions, particularly iron, are present at low levels in biological systems, this pathway (commonly referred to as The Iron-Catalysed HaberWeiss Reaction) has been widely postulated to account for the in vivo generation of the highly reactive ${ }^{\circ} \mathrm{OH}$. If $\cdot \mathrm{OH}$ radicals meet each other, they can form dimers, thus yielding hydrogen peroxide (Bielski et al., 1984):

$\cdot \mathrm{OH}+\cdot \mathrm{OH} \rightarrow \mathrm{H}_{2} \mathrm{O}_{2} k=5 \times 10^{9} \mathrm{M}^{-1} \mathrm{~s}^{-1}$

Although this reaction has a high rate constant very near the diffusion limit (diffusion-controlled), it is unlikely to occur in vivo because the steady-state concentration of $\cdot \mathrm{OH}$ is effectively zero (Hynes et al., 1988). Thus, when produced in vivo ${ }^{\circ} \mathrm{OH}$ reacts close to its site of formation within two molecular diameters (Pryor, 1966). The redox state of the cell is largely linked to the transition metals (iron and copper) and is maintained within strict physiological limits. Preventing metal ions from re- 
dox cycling is an alternative mechanism to inhibit $\cdot \mathrm{OH}$ formation. Reactions of ${ }^{\circ} \mathrm{OH}$ can be classified into three main types:

- hydrogen abstraction

- addition

- electron transfer.

The reaction of $\cdot \mathrm{OH}$ with aromatic compounds often proceeds by addition. For example, ${ }^{\circ} \mathrm{OH}$ adds to the purine base guanine in DNA to form an 8-hydroxyguanine (8-OHdG) radical (Tokiwa et al., 1999). Similarly, $\mathrm{OH}$ can join across a double bond in the pyrimidine base thymine. The thymine radical then undergoes a series of further reactions, e.g. with $\mathrm{O}_{2}$, to give a thymine peroxyl radical (Cadet et al., 2002).

\section{Peroxyl $\left(\mathrm{RO}_{2} \cdot\right)$ and alkoxyl (RO') radicals}

$\mathrm{RO}_{2} \cdot$ and $\mathrm{RO} \cdot$ are good oxidising agents, since they have a tendency to accept electrons thereby undergo reduction themselves having highly positive $E^{\circ}$ values $(\sim 1000-1600 \mathrm{mV})$ (Buettner, 1993; Buettner \& Jurkiewicz, 1996a), although $\mathrm{RO}^{*}$ formed in biological systems often undergoes rapid molecular rearrangement to other radical species. Indeed, $\mathrm{HO}_{2}{ }^{*}$ which is the protonated form (conjugate acid, $\mathrm{pK}_{\mathrm{a}} \sim 4.8$ ) of $\mathrm{O}_{2}{ }^{-}$and is usually termed either hydroperoxyl radical or perhydroxyl radical can be regarded as the simplest $\mathrm{RO}_{2}{ }^{\circ}$. For example, $\mathrm{RO}_{2}$. radicals oxidise ascorbate and $\mathrm{NADH}$, the latter leading to $\mathrm{O}_{2}{ }^{-}$formation in the presence of $\mathrm{O}_{2}$ :

$\mathrm{RO}_{2} \cdot+\mathrm{NADH} \rightarrow \mathrm{RO}_{2} \mathrm{H}+\mathrm{NAD} \cdot$

$\mathrm{NAD} \cdot+\mathrm{O}_{2} \rightarrow \mathrm{NAD}^{+}+\mathrm{O}_{2}^{\cdot-} \mathrm{k} \approx 10^{9} \mathrm{M}^{-1} \mathrm{~s}^{-1}$

Aromatic alkoxyl and peroxyl radicals tend to be less reactive (Casimir, 2006), since electrons can be delocalized into the benzene ring. It has been demonstrated that $\mathrm{RO}_{2}$ initiates fatty acid peroxidation by two parallel pathways: fatty acid hydroperoxide (LOOH)-independent and LOOH-dependent (Aikens \& Dix, 1991). These reactions account for much of the stimulation of lipid peroxidation by transition-metal ions in biological systems. The carbon-centred radicals are capable of reacting directly with certain biological molecules including DNA and albumin - $\mathrm{SH}$-groups. $\mathrm{RO}_{2}$ derived from azo-initiators can induce peroxidation of lipids (Bailey et al., 2004) and can damage proteins, e.g. they inactivate the enzyme lysozyme. The ability of various antioxidants to prevent azo-initiator-induced lipid peroxidation or protein damage is frequently used to assess antioxidant activity, e.g., in the TRAP (Telomere Repeat Amplification Protocol) assay (Falchetti et al., 1998).

\section{Lipid peroxidation (LPO)}

Lipid peroxidation (LPO) has been broadly defined by A. L. Tappel as "oxidative deterioration of polyunsaturated fatty acids (PUFAs) ", i.e. fatty acids that contain more than two carbon-carbon double bonds which are the target of ROS (Tappel \& Dillard, 1981). Polyunsaturated fatty acids are abundant in cellular membranes and in low-density lipoproteins (LDL). The PUFAs allow for fluidity of cellular membranes. The membranes that surround cells and cell organelles contain large amounts of PUFA side-chains (Dietschy, 1998; Chu \& Liu, 2004). Membrane lipids are generally amphipathic molecules, i.e. they contain hydrocarbon regions that tend to cluster together away from water, together with polar parts that like to interact with water. In animal cell membranes the dominant lipids are phospholipids, esters based on the alcohol glycerol (Bartz et al., 2007). Some membranes, particularly plasma membranes, contain significant proportions of sphingolipids and of the hydrophobic molecule cholesterol. The commonest phospholipid in animal cell membranes is lecithin (phosphatidylcholine) (Cherry et al., 2007). Free-radical processes are particularly prone to proceed via efficient chain reactions in which the initiating active radical is generated only in very low concentrations (Gutteridge, 1995; Hwang \& Kim, 2007; Niki et al., 2005).

A typical example of oxidation is the well-known autoxidation reaction which can occur, for example, in lipids when $\mathrm{O}_{2}$ concentration is relatively high. The important point is that, when this type of process occurs, numerous product molecules can be formed for each initiating molecule (Sengpiel et al., 1998; Im et al., 2006; Triggaiani et al., 2006). Thus, what might have been a minor generation of radicals becomes an event of real significance. When a chain-breaking antioxidant such as vitamin $\mathrm{C}$ is added to the solution, it scavenges $\mathrm{LO}^{*}$ and $\mathrm{LO}_{2}{ }_{2}$ radicals and suppresses oxidation. The higher the ascorbic acid concentration, the longer the induction period and the smaller the rate of oxidation during the induction period. The length of induction period is directly proportional to the concentration of vitamin C (Niki, 1991).

Scheme of lipid peroxidation:

$$
\begin{aligned}
& \text { Initiation: } \quad \mathrm{X}^{*}+\mathrm{H}-\mathrm{CR}_{3} \text { (alkyl group) } \rightarrow \mathrm{X}-\mathrm{H}+{ }^{\circ} \mathrm{CR}_{3} \\
& \text { Chain: } \quad \mathrm{CR}_{3}+\mathrm{O}_{2} \rightarrow \mathrm{R}_{3} \mathrm{C}-\mathrm{OO} \cdot \\
& \downarrow \\
& \mathrm{R}_{3} \mathrm{C}-\mathrm{OO}^{*}+\mathrm{H}-\mathrm{CR}_{3} \rightarrow \mathrm{R}_{3} \mathrm{C}-\mathrm{OOH}+{ }^{\circ} \mathrm{CR}_{3} \\
& \text { Termination: } \quad \mathrm{X}^{*}+{ }^{\circ} \mathrm{CR}_{3} \rightarrow \mathrm{R}_{3} \mathrm{C}-\mathrm{X}
\end{aligned}
$$

Overall reaction: $\mathrm{R}_{3} \mathrm{C}-\mathrm{X}+\mathrm{O}_{2} \rightarrow \mathrm{R}_{3} \mathrm{C}-\mathrm{OOH}$

Initiation of LPO is caused by an attack upon a lipid of any species that has sufficient reactivity to abstract a hydrogen atom from a methylene $\left(-\mathrm{CH}_{2}-\right)$ group (Aruoma et al., 1989). Fatty acids with one or no double bonds are more resistant to such attack than are the PUFAs. An adjacent double bond weakens the energy of attachment of the hydrogen atoms present on the next carbon atom, especially if there is a double bond on both sides of the $-\mathrm{CH}_{2}-$, yielding bis-allylic hydrogens. The reduction potential of a PUFA / PUFA couple at $\mathrm{pH}$ 7 has been estimated at about $E^{\circ} \approx+600 \mathrm{mV}$ (Buettner, 1993; Koppenol, 1990). Hence ${ }^{\circ} \mathrm{OH}$, perhydroxyl radical$\mathrm{HO}_{2} \cdot \mathrm{RO}^{\circ}\left(E^{\circ} \approx+1600 \mathrm{mV}\right)$ and $\mathrm{RO}_{2} \cdot\left(E^{\circ} \approx+1000 \mathrm{mV}\right)$ radicals are thermodynamically capable of oxidising PUFAs and initiating peroxidation (Buettner, 1993).

$\mathrm{By}$ contrast, $\mathrm{O}_{2}{ }^{-}$is insufficiently reactive to abstract $\mathrm{H}$ from lipids; in any case, its charge should preclude it from entering the hydrophobic interior membrane. The most likely fate of carbon radicals under aerobic conditions is to combine with $\mathrm{O}_{2}$, especially as $\mathrm{O}_{2}$ is a hydrophobic molecule that concentrates within the interior membranes. The double bond on the carbon atom weakens the carbon-hydrogen bond allowing for easy dissociation of the hydrogen by a free radical. A free radical will steal the single electron from the hydrogen associated with the carbon at the double bond. This in turn leaves the carbon with an unpaired electron and hence it becomes a free radical. In an effort to stabilise the carbon-centred free radical a molecular rearrangement occurs. The newly-arranged molecule is called a conjugated diene $(\mathrm{CD})$. The $\mathrm{CD}$ then very easily reacts with 
oxygen to form a $\mathrm{RO}_{2}$ (Poirier et al., 2001). Formation of peroxyl radicals has been demonstrated during peroxidation of many membrane systems, using spin-trapping methods (Chamulitrat \& Mason, 1989). $\mathrm{RO}_{2}{ }^{\circ}$ are capable of abstracting $\mathrm{H}$ from another lipid molecule, i.e. an adjacent fatty-acid side-chain:

$\mathrm{ROO} \cdot+\mathrm{CH} \rightarrow-\mathrm{ROOH}+\mathrm{C}^{*}$

This is the propagation stage of lipid peroxidation (Svingen et al., 1979). The carbon radical formed can react with $\mathrm{O}_{2}$ to form another $\mathrm{RO}_{2}$ and so the chain reaction of LPO can continue. The $\mathrm{RO}_{2} \cdot$ combines with the hydrogen atom that it abstracted to give a lipid hydroperoxide (LOOH) (Girotti, 1998). This is sometimes shortened to lipid peroxide, although the latter term includes cyclic peroxides as well as $\mathrm{LOOH}$ species. A single initiation event can lead to formation of multiple molecules of peroxide as a result of the chain reaction. Another complexity is that the initial $\mathrm{H}$ abstraction from PUFA can occur at different points on the carbon chain. Thus peroxidation of linoleic acid gives two hydroperoxides, while that of linolenic acid gives four. Peroxidation of arachidonic acid gives six lipid hydroperoxides, while that of docosahexaenoic acid gives ten (Tallman et al., 2001).

Decomposition of lipid peroxides by heating at high temperatures or by exposure to iron or copper ions generates a hugely complex mixture of products, including epoxides, saturated and unsaturated aldehydes, ketones and hydrocarbons. Thermal homolysis of the O-O bond yields radicals, which can attack other hydroperoxides and PUFAs (Halliwell, 2006):

$\mathrm{ROOH} \rightarrow \mathrm{RO}{ }^{*}+{ }^{\cdot} \mathrm{OH}$

Generation within membranes and lipoproteins of $\mathrm{RO}_{2}{ }^{\cdot}$ and $\mathrm{RO}^{*}$, aldehydes and other products of LPO can cause severe damage to the proteins present, e.g., peroxidation of hepatocyte or erythrocyte membranes causes formation of high-molecular-mass protein aggregates within the membrane (Goebel \& Schneider, 1981). The surface receptor molecules that allow cells to respond to hormones and cytokines can be inactivated during LPO, as are enzymes such as glucose-6-phosphatase, glycerol3-phosphate acyl transferase (Thomas \& Poznansky, 1990) involved in maintenance of correct balance within cells. Potassium channels can also be damaged as a consequence of lipid peroxidation (Han et al., 2002).

In general, the overall effects of LPO are to decrease membrane fluidity, make it easier for phospholipids to exchange between the two monolayers, increase the leakiness of the membrane bilayer to substances that do not normally cross it other than through specific channels, and inactivate membrane-bound enzymes. Cross-linking of membrane proteins decreases their lateral and rotational mobility. Continued oxidation of fatty-acid sidechains and their fragmentation to produce aldehydes and hydrocarbons such as pentane will eventually lead to loss of membrane integrity. Peroxidation of erythrocyte membranes causes them to lose their ability to change shape and squeeze through the smallest capillaries (Goebel \& Schneider, 1981; Thomas \& Poznansky, 1990).

Oral administration of large doses of peroxidised fatty acids or lipids to animals leads to disease processes (Armstrong et al., 1984), e.g., heart damage, fatty liver or damage to lymphoid tissues. Not only enzymes but also receptors and transport proteins can be important early targets of oxidative damage. Damage can occur to proteins involved in maintenance of essential ion gradients between cells and extracellular fluids, such as the $\mathrm{Ca}(\mathrm{II})$ -
ATPase and $\mathrm{Ca}(\mathrm{II}) / \mathrm{Na}(\mathrm{I})$ exchange systems that keep intracellular $\mathrm{Ca}(\mathrm{II})$ levels much lower than extracellular levels. The $\mathrm{Na}(\mathrm{I}), \mathrm{K}(\mathrm{I})$-ATPase system in the plasma membranes keeps intracellular $\mathrm{K}(\mathrm{I})$ high and $\mathrm{Na}(\mathrm{I})$ low when compared with levels in extracellular fluids.

In summary, LPO is a free radical-related process that in biological systems may occur under enzymatic control, e.g., for the generation of lipid-derived inflammatory mediators, or non-enzymatically. This latter form is associated mostly with cellular damage as a result of oxidative stress, which also involves cellular antioxidants. It is an important process in oxygen toxicity. Free radicals are generated in a number of metabolic reactions, and lipids containing polyunsaturated fatty acids in cell membranes and lipoproteins are targets of free radical-mediated oxidation (Halliwell \& Gutteridge, 2000). This process of LPO consists of three components: initiation in which free radicals are formed, propagation of the radical chain reactions, and termination (Miller \& Aust, 1988; Porter, 1984; Buettner, 1993). Iron or other catalytic metals usually are required to initiate LPO and the free radicals generated, such as a lipid-derived carbon-centered radical, lipid peroxyl radical ( $\left.\mathrm{LOO}^{\circ}\right)$, and lipid alkoxyl radical $\left(\mathrm{LO}^{\circ}\right)$, propagate the chain reactions. Termination of LPO occurs when the free radicals in the chain propagation step react with other free radicals or antioxidants to form nonradical short-chain hydrocarbon compounds (Scheme 1). Free radicals inflict damage by attacking polyunsaturated fatty acids, thus setting off a deleterious chain reaction that ultimately results in their disintegra-

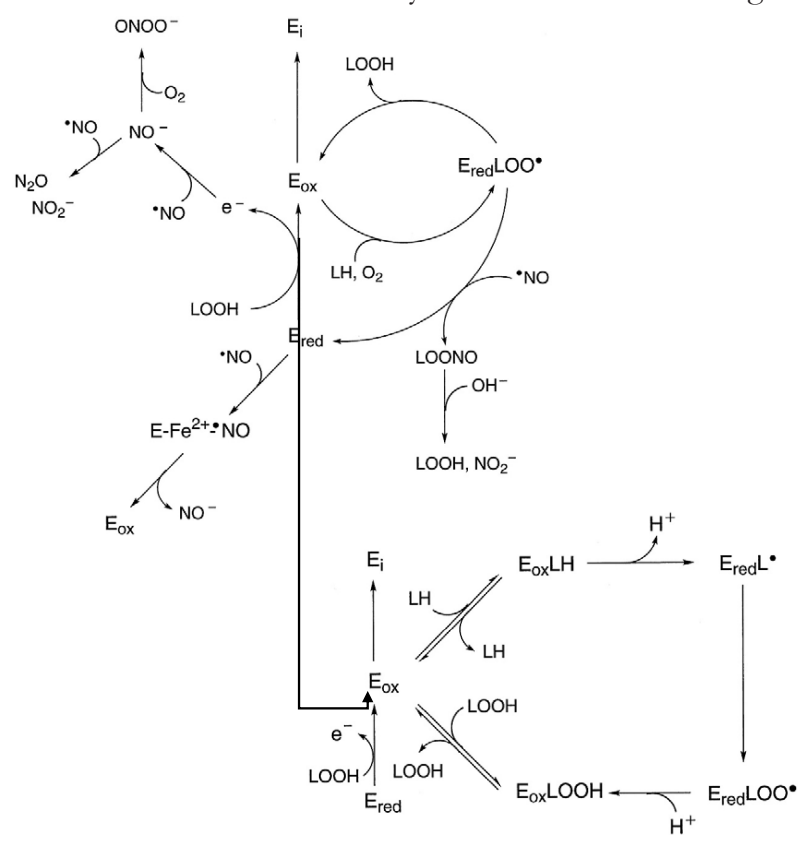

58

Scheme 1. Potential sites of nitric oxide reaction during 15-LOX oxidation of lipid (adapted from O'Donnell et al., 1999).

Three sites of potential NO reaction are shown. (i) During peroxide (LOOH) activation of LOX, 2 mol of NO are consumed via reaction with an electron $\left(\mathrm{e}^{-}\right)$released from the ferrous enzyme $\left(\mathrm{E}_{\mathrm{red}}\right)$ to form nitroxyl anion (NO-). Secondary reactions of NO- will consume further NO- molecules, for example, reaction of $\mathrm{NO}^{-}$with $\mathrm{O}_{2}$ or with further NO molecules, as shown. (ii) During dioxygenase turnover, NO is consumed through reaction with $\mathrm{E}_{\text {red }}$ LOO to form reduced inactive enzyme $\left(E_{\text {red }}\right)$ and an organic peroxynitrite (LONOO). This hydrolyses to the hydroperoxide (LOOH) and nitrite $\left(\mathrm{NO}_{2}{ }^{-}\right)$. (iii) At higher $\mathrm{NO} \cdot$ concentrations a ferrous nitrosyl complex is formed, which slowly decomposes, yielding active enzyme. NO is consumed by enzymatic turnover of LOX. 
tion into malondialdehye, 4 hydroxy-2-nonenal and other harmful by-products. Polyunsaturated fatty acids (PUFA) are believed to be one of the keys for understanding the damage that can be done to cells by free radicals.

Oxidative stress enhances LPO, implicated in the promotion and progression stages of carcinogenesis and development of atherosclerosis, in particular under conditions of chronic inflammation and infections, and in worsening the initial tissue injury caused by ischaemic or traumatic brain damage. Common pathways involve biologically relevant ROS and RNS, which can be generated by biochemical redox reactions, phagocytes, and upregulation of stress-response enzymes like cyclooxygenase-2, lipoxygenases and inducible nitric oxide synthase (Bartsch \& Nair, 2006). The resulting oxidative stress is currently implicated in over 100 human and animal diseases, including cancer, inflammatory, infectious, cardiovascular and neurological diseases. Exocyclic etheno- and propano-DNA adducts, which are formed by LPO endproducts such as 4-hydroxy-2-nonenal and malondialdehyde, are strong pro-mutagenic DNA lesions causing point mutations (Barbati et al., 2010; Valko et al., 2005).

\section{Ascorbate radical (A--)}

Human and animal tissues contains many antioxidants, water-soluble compounds such as ascorbic acid and glutathione and lipid-soluble antioxidants such as $\alpha$-tocopherol and ubiquinones. Ascorbic acid or vitamin $\mathrm{C}$ is especially significant. The most important reaction in the inhibition of oxidation by ascorbic acid must be scavenging of oxygen radicals such as hydroxyl, hydroperoxyl, lipid peroxyl and lipid alkoxyl radicals. It is reported that ascorbic acid reacts with ${ }^{\circ} \mathrm{OH}$ at a rate constant of $7.2 \times 10^{9}-1.3 \times 10^{10} \mathrm{M}^{-1} \mathrm{~s}^{-1}$ depending on the $\mathrm{pH}$ (Bielski, 1982; Cabelli \& Bielski, 1983), which shows that the reaction is very fast and diffusion-controlled. However, this does not mean that vitamin $\mathrm{C}$ is a specific $\cdot \mathrm{OH}$ scavenger, because ${ }^{\circ} \mathrm{OH}$ is so reactive that it can react with many other compounds at about similar rate. Vitamin $\mathrm{C}$ reacts with $\mathrm{O}_{2}{ }^{-}$at a rate constant of $10^{4}-10^{5}$ $\mathrm{M}^{-1} \mathrm{~S}^{-1}$ (Bielski et al., 1975) and scavenges $\mathrm{O}_{2}^{-{ }^{-}}$at a rate constant of $1.6 \times 10^{4} \mathrm{M}^{-1} \mathrm{~s}^{-1}$ (Cabelli \& Bielski, 1983). Singlet oxygen reacts with vitamin $\mathrm{C}$ at a rate constant of $8.30 \times 10^{6} \mathrm{M}^{-1} \mathrm{~s}^{-1}$ (Chou \& Khan, 1983).

Oxidative damage to biomolecules is inhibited by antioxidants. Frei and co-workers (Frei et al., 1988; 1989, Frei \& Gazianot, 1993) have shown that vitamin C is a powerful antioxidant preventing LPO in plasma exposed to various types of oxidative stress. It is known that ascorbate can switch from anti- to pro-oxidant activity in vitro, depending on its concentration and the presence of redox-active metal ions, and thus contribute to the formation of $\mathrm{OH}$, which in turn may cause lipid, DNA, or protein oxidation (Samuni et al., 1983; Bendich et al., 1986). No pro-oxidant effect of ascorbate was observed up to a concentration of $5 \mathrm{mM}$. This confirms that in blood plasma transition metal ions are bound tightly and are not available for free radical reactions. In human plasma ascorbate is the main water-soluble antioxidant (Frei et al., 1989). Compared to average concentrations of ascorbate in human blood plasma $(27-51 \mu \mathrm{M})$ (Lentner, 1984), its levels in human tissues are generally far higher. Its concentration is particularly high in the cornea, lens, and aqueous humor of the eye (up to 1.5 $\mathrm{mM}$ ) and in adrenal and pituitary glands (up to $2.5 \mathrm{mM}$ ). Brain, heart, liver, spleen, kidneys and pancreas also contain high concentrations of ascorbate (up to $0.8 \mathrm{mM}$ ) (Lentner, 1984).
Vitamin C effectively scavenges superoxide and other ROS (Bendich et al., 1986) and plays an important role in the regulation of intracellular redox state through its interaction with glutathione (Meister, 1994; Winkler et al., 1994). Ascorbate is an antioxidant because of the shared ability of the hydroxyl groups on carbons- 2 and -3 to donate a hydrogen atom (both an electron and a proton) to a variety of oxidants, including oxygen- and nitrogenbased free radicals, peroxides and superoxide (Buettner, 1993). Ascorbate oxidation is reversible, which allows for recycling from its oxidised forms. Ascorbate can be oneelectron oxidised by radicals and oxidants in two successive steps. The first one yields $\mathrm{A}^{\bullet-}$, which owing to electron delocalisation over a conjugated tri-carbonyl system is surprisingly stable and can be detected at $10 \mathrm{nM}$ concentrations in biological fluids by EPR (Buettner \& Jurkiewicz, 1993; Coassin et al., 1991; Mehlhorn, 1991), avoiding the detection of artefactual signals arising from freeze/thaw processes (Pietri et al., 1990), and can subsequently be oxidised to dehydroascorbic acid (DHA), unstable and degraded to potentially toxic compounds. In order to prevent the accumulation of toxic ascorbate metabolites, cells are equipped with efficient regenerating systems. One way to achieve this is by transporting extracellular DHA to the cell interior after which it can be reduced to ascorbate. Due to the low reduction potential of the $\mathrm{A}^{-}-\mathrm{AH}-\left(E^{\circ}=+282 \mathrm{mV}\right), \mathrm{AH}^{-}$is able to give up one single electron to any free radical that can arise in biological systems or to regenerate oxidised biological radical scavengers such as vitamin E (Sharma \& Buettner, 1993; Pietri et al., 1990; Vergely et al., 1998). Instead of undergoing further oxidation, two molecules of $\mathrm{A}^{-}$- are thought to react and dismutate to form ascorbate and dehydroascorbate (Bielski et al., 1975). DHA is unstable at physiologic $\mathrm{pH}$, with a half-life of about 6 minutes (Drake et al., 1942; Winkler, 1987). With hydrolysis of the lactone ring it is irreversibly converted to 2,3-diketo-1-gulonic acid (Bode et al., 1990; Chatterjee, 1970). Ascorbate loss due to ring-opening of DHA is wasteful of the vitamin, and cells have developed redundant mechanisms to recycle DHA back to ascorbate (Scheme 2 ). $\mathrm{A}^{\cdot-}$ can be generated by an equilibrium reaction of ascorbate with dehydroascorbic acid, by transition metal-dependent $(\mathrm{Me})$ oxidation of ascorbate or by autoxidation of the ascorbate di-anion (Eqn 10).

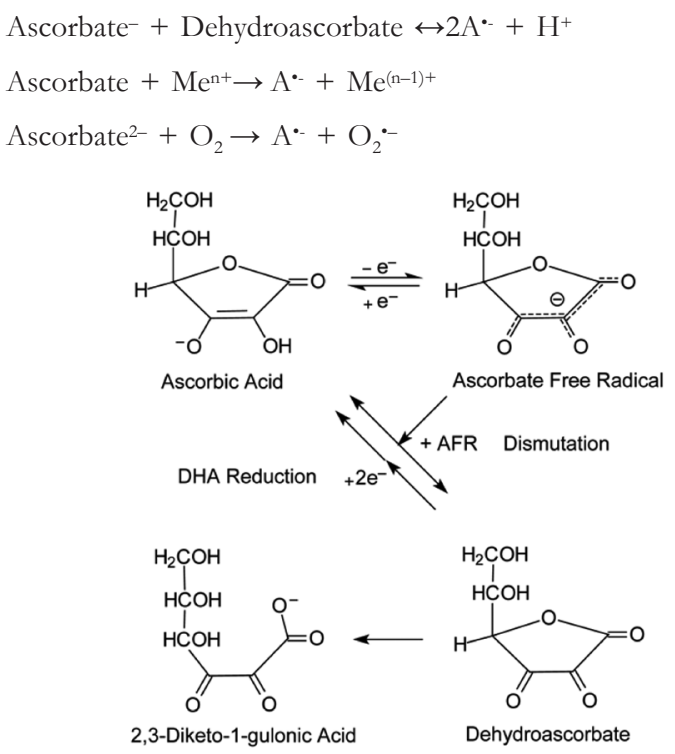

Scheme 2. Ascorbate oxidation and recycling 
The ascorbate anion $\left(\mathrm{AH}^{-}\right)$can be considered the major endogenous water-soluble antioxidant in biological systems. Hence measurement of $\mathrm{A}^{-}$- has been used as a non-invasive biomarker of oxidative stress in humans, e.g., in body fluids and reperfused organs. $\mathrm{A}^{--}$that is generated by donation of a single electron to a radical species is reduced back to ascorbate by NADH-dependent reductases present in microsomal membranes (Lumper et al., 1967; Schulze et al., 1970), as well as by cytosolic thioredoxin reductase (May et al., 1998). A ${ }^{*-}$ reduction occurs with high affinity, with apparent $K_{\mathrm{m}}$ values for $A^{--}$of $2 \mu \mathrm{M}$ or less. Since ascorbate is primarily a one-electron donor, these processes likely account for the bulk of ascorbate recycling in the cell. If there is $A^{*-}$ generated in excess of what the enzyme systems can handle, $\mathrm{A}^{*}$ - dismutation both regenerates ascorbate and forms DHA. The latter is reduced by redundant high capacity but low affinity systems in all mammalian cells. For example, endothelial cells and macrophages possess both GSH and NADPH-dependent mechanisms for recycling ascorbate (May et al., 2001, 2003), although GSHdependent ascorbate recycling has not been observed in HL-60 leukemic cells (Guaiquil et al., 1997) or human skin keratinocytes (Savini et al., 2000). GSH and other cellular thiols can also directly reduce DHA to ascorbate (Winkler et al., 1994), although this process is not as efficient as enzyme-mediated reduction. Since no vascular cells can synthesise ascorbate directly, their intracellular ascorbate concentrations are determined by the combined actions of ascorbate transport into the cell and recycling within the cell.

\section{Singlet oxygen $\left(\mathrm{O}_{2}\right)$}

Singlet oxygen $\left({ }^{1} \mathrm{O}_{2}\right)$ was first observed in 1924 and then defined as a more reactive form of oxygen (Halliwell \& Gutteridge, 2000). It is the most important in biological systems with ample higher energy state molecular oxygen species but is not a radical since it contains no unpaired electrons. Although not a free radial, it can be formed in some radical reactions and also can lead to others since it is one of the most active intermediates involved in chemical and biochemical reactions. We need to remember that its lifetime strongly depends on which solvent it is generated in, e.g. in water it is about $3.8 \mu \mathrm{s}$, in hexane is $31 \mu \mathrm{s}$ and in $\mathrm{C}_{6} \mathrm{~F}_{6}$ (hexafluorobenzene) is about $3900 \mu \mathrm{s}$. (Foote et al., 1995). It has been demonstrated that ${ }^{1} \mathrm{O}_{2}$ can react with many kinds of biological molecules such as DNA, proteins and lipids (Briviba et al., 1997). Since oxygen is ubiquitous and efficiently quenches electronically excited states, ${ }^{1} \mathrm{O}_{2}$ is likely to be formed following irradiation in countless situations and involved in various chemical and biological process as well as in several disease processes which can lead to excessive singlet oxygen formation, especially many different porphyrias (these diseases are caused by defects in the biosynthesis of haem).

Both physical and chemical methods can generate singlet oxygen. Singlet oxygen is most often generated in the laboratory by so called photosensitization reactions (a certain molecule is illuminated with light, absorbs it and the energy raises the molecule into an excited state). Popular sensitizers include the dyes rose Bengal and toluidine blue, but also many biological compounds such as riboflavin, bilirubin or retinal. One well-established reaction used in the laboratory to generate singlet oxygen is the reaction of $\mathrm{H}_{2} \mathrm{O}_{2}$ and the hypochlorite ion $\mathrm{OCl}^{-}$, the ionized form of hypochlorous acid (Kanofsky, 1989);

$\mathrm{OCl}^{-}+\mathrm{H}_{2} \mathrm{O}_{2} \rightarrow \mathrm{Cl}^{-}+\mathrm{H}_{2} \mathrm{O}+{ }^{1} \mathrm{O}_{2}$ (singlet)
Singlet oxygen can react with other molecules either chemically or can transfer upon them its excitation energy, returning to the ground state, while the other molecule (the reaction partner) enters the excited state. The latter phenomenon is known as quenching of singlet oxygen. In the laboratory practice, several compounds are used as singlet oxygen scavengers. They include; azide, histidine, DABCO and 2-phenylisobenzofuran (Foote et al., 1995). It is important to note that tocopherols quench and react with singlet oxygen and might protect membranes against this species (Traber, 1994). ${ }^{1} \mathrm{O}_{2}$ can react directly with carbon-carbon double bonds to give hydroperoxides and cause rapid peroxidation, however, the overall contribution of ${ }^{1} \mathrm{O}_{2}$ to lipid peroxidation is still uncertain.

Singlet oxygen is difficult to detect unambiguously but it can be detected by three different approaches:

- by scavengers: scavengers can inhibit reactions dependent on ${ }^{1} \mathrm{O}_{2}$; for example, azide, carotene, ascorbate, DABCO, thiols and histindine (Wilkinson \& Brummer, 1981; Foote et al., 1995);

- $\mathrm{D}_{2} \mathrm{O}$ (deuterium oxide): $\mathrm{D}_{2} \mathrm{O}$ can be used to detect ${ }^{1} \mathrm{O}_{2}$ since the lifetime of singlet oxygen is 10 -fold longer in $\mathrm{D}_{2} \mathrm{O}$ than in $\mathrm{H}_{2} \mathrm{O}$ (Parker \& Stanbro, 1984). So, if a reaction in aqueous solution is dependent on singlet oxygen, it becomes greatly potentiated when it occurs in $\mathrm{D}_{2} \mathrm{O}$ instead of in $\mathrm{H}_{2} \mathrm{O}$.

- luminescence: as ${ }^{1} \mathrm{O}_{2}$ decays back to the ground state, some of the energy is emitted as light in the infrared region at $1268 \mathrm{~nm}$ (Krinsky, 1979).

Other detection methods include ESR, calorimetry, photo ionization and mass spectroscopy.

\section{Ozone $\left(\mathrm{O}_{3}\right)$}

Ozone is a form of elemental oxygen and is an irritating, acrid-smelling, colourless gas. It is not a free radical but a triatomic oxygen molecule and is much more unstable than $\mathrm{O}_{2}$. It is also a much more powerful oxidizing agent than ground-state oxygen. It is a very reactive gas and even at low concentrations is irritating and toxic. Ozone can be formed when a mixture of $\mathrm{O}_{2}$ and $\mathrm{NO}_{2}$ is exposed to bright light. The concentration of $\mathrm{NO}_{2}$ in air is usually very low, because $\mathrm{N}_{2}$ and $\mathrm{O}_{2}$ do not react at normal temperatures. However, in the hot mixture of gases inside the cylinders of internal combustion engines, nitrogen and oxygen can react:

$\mathrm{N}_{2}+\mathrm{O}_{2} \stackrel{\text { Temp }}{\longrightarrow} 2 \mathrm{NO}$

$\mathrm{NO}$ formed inside car engines reacts spontaneously with $\mathrm{O}_{2}$ in air to form $\mathrm{NO}_{2}$ :

$2 \mathrm{NO}+\mathrm{O}_{2} \rightarrow 2 \mathrm{NO}_{2}$

Nitrogen dioxide is a red-brown gas that dissociates when irradiated with bright light:

$\mathrm{NO}_{2} \mathrm{NO}+\stackrel{\text { light }}{\rightarrow} \mathrm{O}$

The oxygen atom formed in this process is extremely reactive and readily attaches to a molecule of $\mathrm{O}_{2}$, forming ozone.

$\left(\mathrm{O}_{2}+\mathrm{O} \rightarrow \mathrm{O}_{3}\right)$ (Wellburn, 1994).

Ozone levels as low as 0.5 p.p.m can cause lung damage in a few hours and also induce inflammation, activating pulmonary macrophages and recruiting neutrophils to the lung. Damage to macrophages can also decrease resistance to infections. Ozone irritates the eyes and can oxidize proteins and lipids (Schmut et al., 1994; Berlett et al., 1996). Most of the inhaled $\mathrm{O}_{3}$ probably reacts in 
the human body with ascorbate, GSH or urate. These compounds seem especially effective as $\mathrm{O}_{3}$ scavengers. Unlike $\mathrm{NO}_{2}, \mathrm{O}_{3}$ does not appear to directly induce lipid peroxidation, although free radical products resulting from its reactions with PUFAs might be able to do so (Halliwell \& Gutteridge, 2000).

\section{Hydrogen peroxide $\left(\mathrm{H}_{2} \mathrm{O}_{2}\right)$}

Hydrogen peroxide is liquid and is toxic to most cells in the $10-100 \mu \mathrm{M}$ range but is not a free radical, although it can be formed from two ${ }^{\circ} \mathrm{OH}$ radicals:

$\cdot \mathrm{OH}+\cdot \mathrm{OH} \rightarrow \mathrm{H}_{2} \mathrm{O}_{2} k=5 \times 10^{9} \mathrm{M}^{-1} \mathrm{~s}^{-1}$ (Bielski et al., 1984)

Although this reaction has a high rate constant, it is unlikely to occur in vivo since the steady-state concentration of $\cdot \mathrm{OH}$ is effectively zero. Several enzymes can generate $\mathrm{H}_{2} \mathrm{O}_{2}$ in vivo e.g., xanthine, urate, and D-amino acid oxidases. In addition, any biological system that generates $\mathrm{O}_{2}{ }^{-}$will also produce $\mathrm{H}_{2} \mathrm{O}_{2}$ by $\mathrm{O}_{2}{ }^{--}$dismutation. However, $\mathrm{H}_{2} \mathrm{O}_{2}$ is only a weak oxidizing and reducing agent and is generally poorly reactive at physiological levels (Brodie \& Reed, 1987) but is capable of inactivating several enzymes and oxidize keto-acids such as pyruvate and 2-oxoglutarate. It can react with iron and possibly copper to form much more damaging species such as ${ }^{\circ} \mathrm{OH}$. It is important to know that $\mathrm{H}_{2} \mathrm{O}_{2}$ can degrade haem proteins including myoglobin, haemoglobin and cytochrome $c$ (Gutteridge, 1986).

$\mathrm{H}_{2} \mathrm{O}_{2}$ has also been reported to stimulate synthesis of the chemokine MIP- $1 \alpha$ by macrophages (Shi et al., 1996). It can affect the proliferation of cells and facilitate phagocyte adherence to endothelium by up-regulating expression of such adhesion molecules as E-selectin, ICAM-1 and VCAM-1 (Lo et al., 1993). It also leads to oxidative DNA damage by oxo-copper complexes (Zastawny et al., 1995).

$\mathrm{H}_{2} \mathrm{O}_{2}$ production rates by cells and organelles are often in the range of a few nmoles per minute. Therefore, methods for measuring $\mathrm{H}_{2} \mathrm{O}_{2}$ in the biological material should be sufficiently sensitive. These methods include reaction with dichlorofluorescin diacetate, polarographic detection $\left(\mathrm{O}_{2}\right.$ electrode $)$ and histochemical staining methods.

\section{REACTIVE NITROGEN SPECIES (RNS)}

\section{Nitric oxide (NO*)}

Nitric oxide $\left(\mathrm{NO}^{\circ}\right)$ contains an unpaired electron in a $\pi^{*} 2 \mathrm{p}$ antibonding orbital, thus it is a paramagnetic molecule and a free radical. NO ${ }^{*}$ is generated by specific nitric oxide synthases (NOSs), which metabolise arginine to citrulline with the formation of $\mathrm{NO}^{*}$ via a five electron oxidative reaction (Ghafourifar \& Cadenas, 2005) (Scheme 3). It is moderately soluble in water $(7.4 \mathrm{ml} / \mathrm{dl}$ at $0^{\circ} \mathrm{C}$ ) and is more soluble in organic solvents, therefore it can readily diffuse through the cytoplasm and plasma membranes (Chiueth, 1999). In human tissue NO' has a half-life of only a few seconds $(\sim 3-5$ s) (Czapski \& Goldstein, 1995; Ignarro et al., 1993), because it binds avidly with haemoglobin $(\mathrm{Hb})$. It has a greater stability in an environment with a lower oxygen concentration (half-life $\sim 15 \mathrm{~s}$ ). $\mathrm{NO}^{*}$ reacts with molecular oxygen to produce nitrite $\left(\mathrm{NO}_{2}^{-}\right)$(Ignarro et al., 1993; Czapski \& Goldstein, 1995). The kinetics of this reaction was studied by several research groups (Lewis \& Deen, 1994; Kharitonov et al., 1994) and has been found to follow

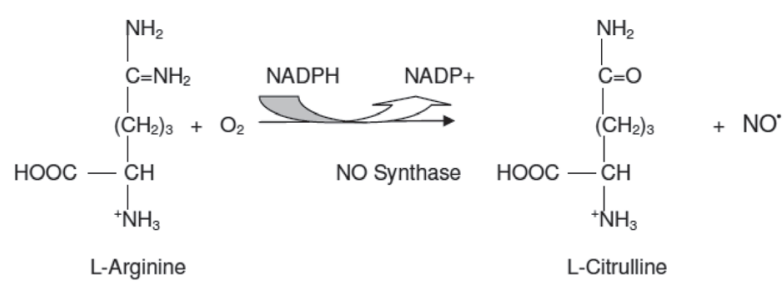

Scheme 3. Oxidation of L-arginine to L-citrulline plus NO. (adapted from Ghafourifar \& Cadenas, 2005)

second order kinetics with respect to $\mathrm{NO}^{*}$ and first order with respect to $\mathrm{O}_{2}$. Inactivation of $\mathrm{NO}^{*}$ in aerobic solutions is therefore governed by a third-order law with an overall rate constant in the range of 6.3 to $11.5 \times 10^{6}$ $\mathrm{M}^{-1} \mathrm{~s}^{-1}$ (Kharitonov et al., 1994; Czapski \& Goldstein, 1995). Consequently, $\mathrm{NO}^{\circ}$ is relatively stable at concentrations in the nanomolar range (half-life of $\sim 80 \mathrm{~min}$ at $100 \mathrm{nM}$ ) but is rapidly inactivated at higher concentrations (half-life of $\sim 50 \mathrm{~s}$ at $10 \mu \mathrm{M}$ ). Therefore, when $\mathrm{NO}^{*}$ is generated by a donor compound the autoxidation reaction will be negligible in the initial phase but will become progressively faster with increasing $\mathrm{NO}{ }^{\bullet}$ concentration. The maximum rate constant of $\mathrm{NO}^{\bullet}$ disappearance was found $\mathrm{k}=2 \times 10^{5} \mathrm{M}^{-1} \mathrm{~s}^{-1}$ due to its binding with $\mathrm{Hb}$ (Hakim et al., 1996). The 4:1 binding ratio between NO and $\mathrm{Hb}$ may be used as a tool to quantitate $\mathrm{NO}^{*}$ release in some biological assays. If the unpaired electron is removed by one-electron oxidation, nitrosonium cation $\left(\mathrm{NO}^{+}\right)$is produced. One-electron reduction would give nitroxyl anion $\left(\mathrm{NO}^{-}\right)$. There are three isoforms of NOS:

neuronal NOS (nNOS) - Type I

inducible NOS (iNOS) — Type II

endothelial NOS (eNOS) — Type III

NO• possesses other unique and important chemical properties that are also critical with respect to its biology. $\mathrm{NO}^{*}$ is almost exclusively a monomeric radical species at room temperature and pressure, so its reactions with other radicals, such as $\mathrm{O}_{2}^{--}$or alkyl radicals, are extremely facile. The inherent radical nature of $\mathrm{NO}^{*}$ and its reactions with other free radicals present in biological systems are important to some of its possible biological actions. For example, it has been proposed that $\mathrm{NO}^{\circ}$ can be toxic through reaction with superoxide $\left(\mathrm{O}_{2}{ }^{-}\right)$to generate peroxynitrite $\left(\mathrm{ONOO}^{-}\right)$, an oxidising agent capable of modifying a variety of biological molecules (Pryor et al., 1994). The reaction of $\mathrm{NO}^{\circ}$ with $\mathrm{O}_{2}$ generates species such as nitrogen dioxide $\left(\mathrm{NO}_{2}\right)$ and dinitrogen trioxide $\left(\mathrm{N}_{2} \mathrm{O}_{3}\right)$ that may have biological significance. Dinitrogen trioxide is a potent nitrosating agent that can alter protein function via nitrosation of critical nucleophilic residues (Eqn 11) (Kissner et al., 1997).

$$
\begin{aligned}
& \mathrm{NO}^{\circ}+\mathrm{O}_{2} \rightarrow \text { OONO } \quad k=1.9 \times 10^{10} \mathrm{M}^{-1} \mathrm{~s}^{-1} \\
& \cdot \mathrm{OONO}+\mathrm{NO}^{\cdot} \rightarrow \text { ONOONO } \\
& \downarrow \\
& \mathrm{ONOONO} \rightarrow \mathrm{NO}_{2} \rightarrow \text { Lipid peroxidation, vasodilatation at low } \mathrm{pO}_{2} \\
& \downarrow \\
& \mathrm{NO}_{2}+\mathrm{NO}^{*} \rightarrow \mathrm{N}_{2} \mathrm{O}_{3}
\end{aligned}
$$


$\mathrm{NO}_{2}$ is also a free radical species that, unlike $\mathrm{NO}^{\circ}$, is a fairly potent oxidant, $E^{\circ}$ for the $\mathrm{NO}_{2} / \mathrm{NO}_{2}^{-}$couple $=1040 \mathrm{mV}$. There are a variety of potential reaction pathways by which $\mathrm{NO}_{2}$ can cause oxidation of biological molecules: hydrogen atom abstraction, addition to unsaturated bonds, and electron transfer reactions (Huie, 1994). However, it has been postulated that the lipophilicity of $\mathrm{NO}^{*}$ and $\mathrm{O}_{2}$ allows their concentration to be high enough for this reaction to occur within cell membranes (Liu et al., 1998). The chemistry of reactions of $\mathrm{NO}^{*}$ and derived species with thiols appears to be an important aspect of NO• biology (Stamler, 1995). Modification of biological molecules by $\mathrm{NO}^{*}$ may occur via reaction with a thiol function; for example, nitrosothiols (RSNO) can be formed by reaction with $\mathrm{NO}^{*}$ or, more likely, $\mathrm{NO}^{-}$-derived species. RSNO formation can be accomplished by the mechanism shown in Eqn 13 with a nucleophilic thiol. Also, RSNO formation has been postulated to occur via direct reaction of $\mathrm{NO}^{*}$ with a thiol followed by reaction of the thiol-NO ${ }^{*}$ intermediate with $\mathrm{O}_{2}$ (Eqns 12, 13) (Gow et al., 1997).

$\mathrm{NO} \cdot+\mathrm{RSH} \rightarrow \mathrm{RSN} \cdot-\mathrm{OH}$

$\mathrm{RSN} \cdot-\mathrm{OH}+\mathrm{O}_{2} \rightarrow \mathrm{RSNO}+\mathrm{O}_{2}^{\cdot-}+\mathrm{H}^{+}$

Finally, RSNO formation can occur via metal-mediated processes whereby the metal binds $\mathrm{NO}^{*}$ and acts as an electron acceptor when reacted with a thiol (Wayland \& Olson, 1974; Liu et al., 1998; Wade \& Castro, 1990; Ford 2004). This chemistry can be accomplished by, for example, ferric haem proteins, ultimately resulting in the generation of a ferrous nitrosyl adduct $\left(\mathrm{M}^{\mathrm{n}}=\right.$ $\mathrm{Fe}^{3+}$-haem, $\mathrm{M}^{\mathrm{n}-1}=\mathrm{Fe}^{2+}$-haem) in a process referred to as "reductive nitrosylation." As indicated above, NO• can react with $\mathrm{O}_{2}^{-}$to generate potentially deleterious oxidants such as peroxynitrite $\left(\mathrm{ONOO}^{-}\right)$and $\mathrm{NO}_{2}$ (Hsiai et al., 2007; Patcher et al., 2007). Indeed, it has been hypothesised that much of the toxicity associated with high levels of $\mathrm{NO}^{*}$ is a result of formation of these oxidants. However, the ability of $\mathrm{NO}^{*}$ to react with radicals also predicts that it can have antioxidant properties. That is, $\mathrm{NO}^{*}$ can combine with another radical leading to termination of radical chain reactions. Probably the best example of the antioxidant properties of $\mathrm{NO}^{*}$ is the effect it can have on lipid peroxidation (Wink et al., 1993; Hogg et al., 1993; Rubbo et al., 1994, 1995; Struck et al., $1995)$. Free radical chain processes occur in membranes because the membrane PUFA are susceptible to radical initiation processes and undergo the well-known PUFA radical chain autoxidaton (Pryor, 1966, 1976). Lipid alkoxyl ( $\mathrm{LO}^{*}$ ) and peroxyl (LOO*) radicals are important intermediates in these lipid autoxidation processes. Nitric oxide can behave as an antioxidant or as a pro-oxidant in lipid autoxidations, depending on the experimental conditions (O’Donnell et al., 1997; 1999; O’Donnell \& Freeman, 2001; Hiramoto et al., 2003). The antioxidant action of $\mathrm{NO}^{\circ}$ occurs by chain-breaking termination reactions of $\mathrm{NO}^{*}$ with $\mathrm{LO}^{*}$ and $\mathrm{LOO}^{*}$ radicals, as in Eqns 14,15 .

$\mathrm{LO}^{*}+\mathrm{NO} \cdot \rightarrow \mathrm{LONO}$

$\mathrm{LOO}^{*}+\mathrm{NO}^{*} \rightarrow$ LOONO

The reaction of nitric oxide with $\mathrm{LOO}^{-}$results in the formation of an alkyl peroxynitrite (LOONO) which can homolyse to generate a geminate radical pair, $\mathrm{NO}_{2}$ and an alkoxyl radical $\left(\mathrm{LO}^{\circ}\right)$. Both of these radicals can initiate further radical reactions (Goldstein et al., 2004; Zhao et al., 2004). About $86 \%$ of these radical pairs from LOONO rapidly recombine to give unreactive alkyl nitrates $\left(\mathrm{LONO}_{2}\right)$ (Goldstein et al., 2004), indicating that
$\mathrm{NO}^{*}$ can be an effective antioxidant. However, the remaining $14 \%$ of the radical pairs formed in the homolysis of LOONO become free $\mathrm{NO}_{2}$ and LO radicals (Eqs 16, 17) (Abuja et al., 1997).

$\mathrm{LOONO} \rightarrow \mathrm{LO} \cdot+\mathrm{NO}_{2}(14 \%$ yield $)$

$\mathrm{LOONO} \rightarrow \mathrm{LONO}_{2}(86 \%$ yield $)$

Thus, $14 \%$ of the $\mathrm{NO}^{*}$ and $\mathrm{LOO}^{*}$ radicals that react to form LOONO get effectively converted into $\mathrm{NO}_{2}$ and $\mathrm{LO}^{\circ}$, a much more reactive pair. For instance, in abstracting a hydrogen atom from a doubly allylic position, the rate constants for $\mathrm{LOO}^{*}$ and $\mathrm{LO}^{*}$ are $31 \mathrm{M}^{-1} \mathrm{~s}^{-1}$ and $\sim 10^{7} \mathrm{M}^{-1} \mathrm{~s}^{-1}$, respectively (Abuja et al., 1997), and although $\mathrm{NO}^{*}$ cannot abstract a hydrogen atom from a doubly allylic position in a PUFA, the rate constant for the reaction of $\mathrm{NO}_{2}$ with linoleic acid is $2 \times 10^{5} \mathrm{M}^{-1} \mathrm{~s}^{-1}$ (Prutz et al., 1985). In summary, through the sum of reactions $15-17,86^{\circ}$ of the $\mathrm{LOO}^{\circ}$ and $\mathrm{NO}^{\circ}$ radicals go on to form the stable product $\mathrm{LONO}_{2}$, and $14 \%$ form the more reactive radicals $\mathrm{LO}^{*}$ and $\mathrm{NO}_{2}$.

Although $\mathrm{NO}_{2}$ is a more reactive and a more powerful oxidant than is $\mathrm{NO}^{\circ}$, reactions of $\mathrm{NO}_{2}$ with closedshell molecules are relatively slow compared with those of $\cdot \mathrm{OH}$. However, $\mathrm{NO}_{2}$ reacts rapidly with other radicals. This is one reason nitrotyrosine is formed from the reaction of $\mathrm{NO}_{2}$ with protein tyrosyl radicals (Squadrito \& Pryor, 2002).

$\mathrm{NO}_{2}+\mathrm{O}_{2}^{--} \rightarrow \mathrm{O}_{2} \mathrm{NOO}^{-}$

Just as the rate of reaction of $\mathrm{NO}^{-}$with $\mathrm{O}_{2}^{-{ }^{-}}$(Eqn 18) to form $\mathrm{ONOO}^{-}$is fast and close to the diffusion limit $\left(k=3.8-6.7 \times 10^{9} \mathrm{M}^{-1} \mathrm{~s}^{-1}\right)$ (Huie \& Padmaja, 1993; Goldstein et al., 1995; Kobayashi et al., 1995), so is the reaction of $\mathrm{NO}_{2}$ with $\mathrm{O}_{2}{ }^{--}$to form peroxynitrate fast $\left(k=4.5 \times 10^{9} \mathrm{M}^{-1} \mathrm{~s}^{-1}\right)$ (Løgager \& Sehested, 1993). This rate is approximately three times greater than that of the superoxide dismutase-catalysed dismutation of $\mathrm{O}_{2}{ }^{--}$. Therefore $\mathrm{NO}^{*}$ is capable of outcompeting SOD for $\mathrm{O}_{2}^{-}$in conditions such as atherosclerosis, I-R, increased shear stress and exercise, in which production of $\mathrm{NO}^{*}$ and $\mathrm{O}_{2}^{-}$is concomitantly increased. This implies that when both $\mathrm{O}_{2}{ }^{-}$and $\mathrm{NO}_{2}$ are present in the same environment, they will most likely react to form peroxynitrate. Because of the higher reactivity of $\mathrm{NO}_{2}$ relative to $\mathrm{NO}^{*}$, the formation of peroxynitrate might be somewhat less likely than the formation of $\mathrm{ONOO}^{-}$. Nevertheless, $\mathrm{ONOO}^{-}$appears to be formed under a variety of experimental conditions. Goldstein and collaborators (Goldstein et al., 1998; Hodges \& Ingold, 1999; Alvarez \& Radi, 2001; Kirsch et al., 2001), Uppu and collaborators (Uppu et al., 2000) and others have implicated peroxynitrate during the in vitro decomposition of $\mathrm{ONOO}^{-}$in the presence of certain substrates that lead to the formation of $\mathrm{O}_{2}^{-{ }^{-}}$and $\mathrm{NO}_{2}$. Since $\mathrm{O}_{2}^{--}$is ubiquitous in aerobic organisms and $\mathrm{NO}_{2}$ can be formed endogenously by several pathways, the formation of peroxynitrate could be more widespread than presently recognised, and possible roles for $\mathrm{ONOO}^{-}$in oxidative biology should be studied further. The biochemistry of peroxynitrate is very different from that of $\mathrm{ONOO}^{-}$. For example, in contrast to $\mathrm{ONOO}^{-}$, for peroxynitrate it is the conjugate base $\left(\mathrm{O}_{2} \mathrm{NOO}^{-}\right)$that is kinetically unstable. Biological oxidations by peroxynitrate would then result from reactive intermediates that are formed during its decomposition and/or from direct oxidations by peroxynitrate. For example, theoretical and experimental data suggest that singlet oxygen (Eqn 19) may be produced during the unassisted decomposition of peroxynitrate (Goldstein et al., 1998; Khan et al., 2000; Martinez et al., 2000; Merenyi 
et al., 2000; Olson et al., 2003). Peroxynitrate $\left(\mathrm{O}_{2} \mathrm{NOO}^{-}\right)$ is a more powerful two-electron oxidant than peroxynitrite; their reduction potentials are $E^{\circ}(\mathrm{pH} 7)=1.59 \mathrm{~V}$ vs $E^{\circ}(\mathrm{pH} 7)=1.37 \mathrm{~V}$, respectively (Goldstein et al., 1998). Knowledge of the reaction kinetics of peroxynitrate with biological molecules is very limited. The kinetics of the reaction of peroxynitrate with methionine were studied recently, affording $k=34 \mathrm{M}^{-1} \mathrm{~s}^{-1}$ at $\mathrm{pH} 7.4$ and $25^{\circ} \mathrm{C}$ (Squadrito \& Pryor, 2002), which compares with 181 $\mathrm{M}^{-1} \mathrm{~S}^{-1}$ for the reaction of methionine with $\mathrm{ONOO}^{-}$under similar conditions (Pryor et al., 1994). We are only beginning to understand the delicate interplay of the radical reactions and the generation of secondary reactive species downstream from the formation of $\mathrm{NO}^{\bullet}$ and how these reactions can integrate with biochemical processes.

$$
\mathrm{O}_{2} \mathrm{NOO} \rightarrow{ }^{1} \mathrm{O}_{2} \text { (singlet) }+\mathrm{NO}_{2}^{-}
$$

$\mathrm{NO}^{*}$ is an abundant reactive radical that acts as an important oxidative biological signalling molecule in physiological processes including neurotransmission, blood pressure regulation, defence mechanisms, smooth muscle relaxation or immune regulation (Bergendi et al., 1999). Interest in $\mathrm{NO}^{*}$ arose because of the discovery of its multiple important physiological roles (Gow et al., 2000; Stratford et al., 1997). NO* normally functions not only to reduce platelet aggregation and leukocyte adhesion to the endothelium, but to promote vascular smooth muscle relaxation and reduce endothelial cell cytokine production. $\mathrm{NO}^{*}$ concentrates in lipophilic cellular regions with a partition coefficient of 8:1, and can inhibit LPO e.g., by 15-lipoxygenase (15-LOX), a thousand times more potently than $\alpha$-tocopherol (O'Donnell et al., 1999). NO• has effects on neuronal transmission as well as on synaptic plasticity in the central nervous system. In the extracellular milieu nitric oxide reacts with oxygen and water to form nitrate $\left(\mathrm{NO}_{3}^{-}\right)$and nitrite $\left(\mathrm{NO}_{2}^{-}\right)$ anions (Bryan, 2006). Since $\mathrm{NO}^{\bullet}$ relaxes smooth muscle in blood vessel walls resulting in lower blood pressure, $\mathrm{O}_{2}{ }^{-}$can be a vasoconstrictor by removing NO'. Thus, excessive vascular $\mathrm{O}_{2}{ }^{-}$- production could contribute to hypertension and vasospasm (Darsley-Usmar et al., 1995; Bailey et al., 2010).

A role for $\mathrm{NO}^{*}$ has also been demonstrated in such human diseases as malaria where $\mathrm{NO}^{\circ}$ appears to be partly involved in resistance to malarial infection (Riley et al., 2006), in cardiovascular disease (Levy et al., 2009; Strijdom et al., 2009; Rudolph \& Freeman, 2009), acute inflammation (Tilg \& Moschen, 2008), cancer (Nanni et al., 2009; Parkins et al., 1995), neurodegenerative diseases (Knott \& Bossy-Wetzel, 2009; Zhu et al., 2007), and diabetes (Szabo, 2009; Dawson et al., 2009; Sobrevia \& Mann, 1997). In inflammatory conditions, such as occurs in reperfusion, inducible nitric oxide synthetase can increase nitric oxide concentration to thousands of times normal levels. During reperfusion, abnormally high amounts of $\mathrm{O}_{2}{ }^{-}$convert almost all available $\mathrm{NO}^{-}$to $\mathrm{ONOO}^{-}$regarded as the agent causing most of the damage to brain capillary endothelial cells (Schaller \& Graf, 2004). Damage to the endothelium not only increases oedema (tissue swelling due to "leakiness"), but causes endothelial protrusions "blebbs" which can block capillaries (Ono et al., 1993). Moreover, $\mathrm{NO}^{*}$ has been implicated in adult respiratory distress syndrome, septic shock, hypertension, thrombosis, renal failure, AIDS encephalopathy, bronchospasm, stroke and male impotence (Bailey et al., 2009; Canning et al., 2001; Adamson et al., 1996; Maree et al., 1994). Nitric oxide readily binds certain transition metal ions, and many of its physiological effects are exerted as a result of its initial binding to $\mathrm{Fe}^{2+}$ haem groups in the enzyme guanylate cyclase (Archer et al., 1993). For example, NO• synthesised by the vascular endothelial cells that line the interior of blood vessels presumably diffuses in all directions, but some of it will reach the underlying smooth muscle, bind to guanylate cyclase and active it. As a result more cyclic GMP is made, which lowers intracellular free $\mathrm{Ca}^{2+}$ and relaxes the muscle, dilating the vessel and lowering blood pressure (Torfgard \& Adler, 1994).

\section{TRANSITION METAL IONS}

All metals in the first row of the d-block in the periodic table, except zinc, contain unpaired electrons and can thus qualify as free radicals. The ability of transition metal ions to undergo facile one-electron oxidation or reduction makes them obvious potential chemical partners for reactions involving biological free radicals with advantageous or deleterious biological effects. Iron is by far the most abundant transition metal in the human body where it plays a role in oxygen binding (haemoglobin) and electron transport. It is therefore a potential mediator of ${ }^{\circ} \mathrm{OH}$ generation under normal physiological conditions in the iron/ copper-catalysed Haber-Weiss reaction. Because of the central and essential roles of iron in the metabolism of all aerobic organisms, humans have evolved some peculiar ways of dealing with it. These peculiarities provide opportunities to cause diseases related to iron absorption, transport, and metabolism, as well as for the exacerbation of general mechanisms of disease involving free radical injury. Iron-catalysed generation of ROS has been implicated in the pathogenesis of many disorders including atherosclerosis (Salonen et al., 1992) cancer (Loeb et al., 1988), ischaemia reperfusion injury (White et al., 1985; Katoh et al., 1992) and conditions of iron overload (Burkitt \& Mason, 1991), such as haemochromatosis, which is one of the most prevalent genetic disorders in Western countries. The excess iron induces cellular injury and functional abnormalities in hepatocytes by lipid peroxidation in lysosomal, mitochondrial and microsomal membranes (Britton et al., 1987). Lipid peroxidation is a likely outcome of oxidative stress in biological systems, and its measurement is often used as a method of assessing the degree of oxidative damage.

\section{The Fenton chemistry}

Fenton chemistry is a prime example of damaging free radical reactions catalysed by transition metals. A mixture of $\mathrm{H}_{2} \mathrm{O}_{2}$ with a $\mathrm{Fe}^{2+}$ salt oxidises many different organic molecules and can provoke a whole series of radical reaction. In vivo, ${ }^{\circ} \mathrm{OH}$ are most likely generated from superoxide anions via an iron-catalysed Fenton reaction (Halliwell, 1982).

EPR (electron paramagnetic resonance spectroscopy) studies demonstrated the ability of iron bound to transferrin to catalyse ${ }^{\circ} \mathrm{OH}$ formation in the presence of $\mathrm{O}_{2}{ }^{--}$ (Bannister et al., 1982). However, these results have subsequently been questioned (Baldwin et al., 1984). Another source of iron is the intracellular pool, where iron is principally bound to ferritin. It has been recently shown in vitro that $\mathrm{O}_{2}{ }^{-}$is capable of releasing iron from ferritin, thereby allowing the formation of $\cdot \mathrm{OH}$ (Thomas et al., 1985). Alternatively, the presence of low molecu- 
lar weight iron chelates has been hypothesised (Jacobs, 1977).

The mechanism of $\mathrm{Fe}^{2+}$-initiated Fenton reaction is as follows:

rate constant $\left(\mathrm{M}^{-1} \mathrm{~s}^{-1}\right)$ at $\mathrm{pH}=5$

(Walling, 1975; Kwan \& Voelker, 2002)

a. $\mathrm{Fe}^{2+}+\mathrm{H}_{2} \mathrm{O}_{2} \rightarrow \mathrm{Fe}^{3+}+\cdot \mathrm{OH}+\mathrm{OH}^{-} k=5.7 \times 10^{2} \mathrm{M}^{-1} \mathrm{~s}^{-1}$

b. $\mathrm{Fe}^{3+}+\mathrm{H}_{2} \mathrm{O}_{2} \rightarrow \mathrm{Fe}^{2+}+\mathrm{HO}_{2} / \mathrm{O}_{2}^{-}+\mathrm{H}^{+} k=2.6 \times 10^{-3} \mathrm{M}^{-1} \mathrm{~s}^{-1}$

c. $\mathrm{H}_{2} \mathrm{O}_{2}+\cdot \mathrm{OH} \rightarrow \mathrm{HO}_{2} / \mathrm{O}_{2}^{-}+\mathrm{H}_{2} \mathrm{O} k=3.3 \times 10^{7} \mathrm{M}^{-1} \mathrm{~s}^{-1}$

d. $\mathrm{Fe}^{3+}+\mathrm{HO}_{2} / \mathrm{O}_{2}^{-} \rightarrow \mathrm{Fe}^{2+}+\mathrm{O}_{2}+\mathrm{H}^{+} k=3.1 \times 10^{5} \mathrm{M}^{-1} \mathrm{~s}^{-1}$

e. $\mathrm{Fe}^{2+}+\cdot \mathrm{OH} \rightarrow \mathrm{Fe}^{3+}+\mathrm{OH}^{-} k=3.2 \times 10^{8} \mathrm{M}^{-1} \mathrm{~s}^{-1}$

f. $\mathrm{Fe}^{2+}+\mathrm{HO}_{2} / \mathrm{O}_{2}^{-} \rightarrow \mathrm{Fe}^{3+}+\mathrm{H}_{2} \mathrm{O}_{2} k=6.6 \times 10^{6} \mathrm{M}^{-1} \mathrm{~s}^{-1}$

g. $\mathrm{HO}_{2} / \mathrm{O}_{2}^{-}+\mathrm{HO}_{2} / \mathrm{O}_{2}^{-} \rightarrow \mathrm{H}_{2} \mathrm{O}_{2} k=2.3 \times 10^{6} \mathrm{M}^{-1} \mathrm{~s}^{-1}$

h. $\cdot \mathrm{OH}+\mathrm{HO}_{2} / \mathrm{O}_{2} \rightarrow \mathrm{H}_{2} \mathrm{O}+\mathrm{O}_{2} k=8.9 \times 10^{9} \mathrm{M}^{-1} \mathrm{~s}^{-1}$

i. $\cdot \mathrm{OH}+\cdot \mathrm{OH} \rightarrow \mathrm{H}_{2} \mathrm{O}_{2} k=5.2 \times 10^{9} \mathrm{M}^{-1} \mathrm{~s}^{-1}$

The generally accepted mechanism for the Fenton process identifies $\mathrm{OH}$ as the active oxidising intermediate in the system (Haber \& Weiss, 1932, 1934; Barb et al., 1951; Walling, 1975). According to this mechanism (Eqn 20), the combination of ferrous iron and hydrogen peroxide induces a series of chain reactions initiated by the degradation of peroxide to ${ }^{\circ} \mathrm{OH}$ and the hydroxide ion (reaction 20a). The hydroxyl radical serves as a chain carrier that may react with $\mathrm{Fe}^{2+}, \mathrm{H}_{2} \mathrm{O}_{2}$, or any organic species present. These reactions may either propagate the chain cycle through the production of additional radicals (superoxide and its conjugate acid, reaction 20c) that can reduce $\mathrm{Fe}^{3+}$ back to $\mathrm{Fe}^{2+}$ (reaction 20d), or terminate the chain by oxidising $\mathrm{Fe}^{2+}$ (reactions 20e, f). When reaction $20 \mathrm{~b}$ is taken into account, $\mathrm{Fe}^{3+}$ may also be considered a chain carrier, producing $\mathrm{Fe}^{2+}$ and superoxide, although this cycling occurs at a much slower rate $\left(k_{2} \ll k_{3}, k_{4}\right)$. Additional chain termination reactions include the minor radical-radical recombination pathways (reactions 20f, g, h). Depending on the type of organic species present, reactions with ${ }^{\circ} \mathrm{OH}$ may either propagate the chain by producing $\mathrm{HO}_{2}{ }^{*} / \mathrm{O}_{2}{ }^{-}-$or organic radicals capable of reducing $\mathrm{Fe}^{3+}$ directly, or terminate the cycle by scavenging ${ }^{\circ} \mathrm{OH}$ (Walling, 1975). Extrapolated to biological systems, this information suggests that tissues exposed to an increased concentration of iron and/or copper (e.g., liberated from internal stores) may be prone to oxidative damage related to the metal ion- $\mathrm{O}_{2}$-mediated free radical production. This might indeed be so, because transition metals, when liberated from intracellular stores, are probably present in reduced forms (Keyer \& Imlay, 1996; Qian \& Buettner, 1999). If it is taken for granted that an increased pool of low molecular mass iron and copper is present in ischaemic tissues (Nayni et al., 1985; Gower et al., 1989; Voogd et al., 1992), it becomes apparent that reperfusion, which induces tissue injury in a mechanism involving $\cdot \mathrm{OH}$ (Bolli, 1991), creates particularly favourable conditions for the metal ion- $\mathrm{O}_{2}$ reaction to occur. This is because:

- this reaction is fast enough to account for the reperfusion-induced production of free radicals;

- $\mathrm{O}_{2}$, catalytic metals, and their reductants (including enzymatically produced $\mathrm{O}_{2}{ }^{-}$) are abundant;

- intracellular pH rapidly increases (Bauza et al., 1995) in the reperfused tissue (Harris \& Aisen, 1973) and facilitates metal ion- $\mathrm{O}_{2}$ chemistry.

Oxygen-derived active species, including free radicals, have been implicated in tissue injury following ischaemia and reperfusion of the heart (McCord, 1985; Garlick et al., 1987; Arroyo et al., 1987; Zweier et al., 1987) and brain (Krause et al., 1988; Cao et al., 1988; Watson \& Ginsberg, 1989) as well as in various other pathologies (Halliwell \& Gutteridge, 1984). Their production from relatively low-reactive species has been proposed to be mediated by redox-active metal ions (Aust et al., 1985; Chevion, 1988). Indeed, circumstantial evidence has been presented to support the causative role of newly mobilised redox-active iron in tissue injury (Nayini et al., 1985; Holt et al., 1986). Iron chelation provides protection against tissue injury following ischaemia (Myers et al., 1985, 1986), whereas the addition of $\mathrm{Fe}^{3+}$ and $\mathrm{Fe}^{2+}$ to the perfusate increased the rate of injury in hearts subjected to ischaemia and reperfusion (Bernier et al., 1986; Karwatowska-Prokopczuk et al., 1992). The recovery of myocardial high-energy phosphate metabolism and left ventricular contractility after a period of global ischaemia suggest that iron-catalysed $\cdot \mathrm{OH}$ formation plays a key role in the pathogenesis of reperfusion injury. Despite these theoretical considerations, relatively little is known about the role of iron in the pathogenesis of postischaemic damage.

\section{CONCLUSIONS}

The radicals $\mathrm{NO}\left(\mathrm{NO}^{*}\right)$ and superoxide anion $\left(\mathrm{O}_{2}{ }^{-}\right)$ play an important role in biological regulation. Superoxide gives rise to other forms of ROS that serve as mediators in many regulatory processes. Most redoxresponsive regulatory mechanisms in bacteria and mammalian cells serve to protect the cells against oxidative stress and to reestablish redox homeostasis. The oxidative induction of protective enzymes by proteins or the inhibition of NOS by NO are prominent examples. Redox regulation of other physiological responses in higher organisms is embedded in these basic mechanisms of redox homeostasis. The relatively large number of isoforms of $\mathrm{NAD}(\mathrm{P}) \mathrm{H}$ oxidase and NOS indicates that nature has "learned" to use free radicals to her advantage in processes not directly related to protection against oxidative stress. The production of superoxide and NO, respectively, by these enzymes is strictly regulated by hormones, cytokines, or other inducing mechanisms. The resulting oxidative species, in turn, act as secondary messengers to control a variety of physiological responses. The regulation of vascular smooth muscle relaxation, the monitoring of the oxygen concentration in the regulation of respiratory ventilation and erythropoietin production, and the enhancement of signaling cascades from various membrane receptors are prominent examples. The enhancement of signal transduction from a given receptor by stimulation of ROS production through this or other receptors may serve two physiological purposes.

First, it provides a basis for cooperativity, and second, the membrane receptor may function simultaneously as a sensor for the extracellular ligand and as a sensor for the inner metabolic state of the individual cell. The cooperativity between angiotensin II receptor and EGF receptor is a well-studied example, but other examples will likely be found. Because hydrogen peroxide has a relatively long half-life and crosses membranes, the cooperativity principle may even extend to other cells in the vicinity. By enhancing the intracellular signaling pathways of lymphocytes, ROS from activated macrophages and neutrophils may contribute decisively to the activation of the antigen-specific immune response and may allow the immune system to respond to minute amounts of invading pathogens. Signaling pathways involving JNK, p38 MAPK, and the transcription factors AP-1 and NF- $x B$ are particularly responsive to redox regulation. The capacity of ROS to damage proteins and to hasten their proteolytic degradation has been employed as a regula- 
tory mechanism in several cases, e.g., in the degradation of the transcription factor subunit HIF- $1 \alpha$ and the $\mathrm{NF}-x \mathrm{~B}$ inhibitor $\mathrm{I} x \mathrm{~B}$. The inhibition of protein tyrosine phosphatases is well-defined on a molecular basis and provides an example of redox regulation by loss of function. In other cases, NO or ROS induce a gain of function in a signaling protein. This mechanism is involved in the regulation of vascular tone and the functional activation of bacterial proteins. The oxidative enhancement of membrane receptor signaling and the corresponding downstream signaling pathways are not well-characterized at the molecular level but are likely to involve a simultaneous induction of several different redox-sensitive signaling proteins. This redundancy does not preclude selective effects. The in vivo relevance of redox-sensitive signaling cascades is strongly suggested by the mere existence of the many $\mathrm{NAD}(\mathrm{P}) \mathrm{H}$ oxidase isoforms and by the apparent dysregulation of physiological responses in various disease-related oxidative stress conditions. However, the relative contributions of individual redox-sensitive signaling proteins to redox-regulated processes in vivo are presently obscure.

\section{REFERENCES}

Abuja PM, Albertini R, Esterbauer H (1997) Simulation of the induction of oxidation of low-density lipoprotein by high copper concentrations: evidence for a nonconstant rate of initiation. Chem Res Toxicol 10: 644-651.

Adamson DC, Wildemann B, Sasaki M, Glass JD, McArthur JC, Christov VI, Dawson TM, Dawson VL (1996) Immunologic NO synthase: elevation in severe AIDS dementia and induction by HIV-1 gp41. Science 274: 1917-1921.

Aikens J, Dix TA (1991) Perhydroxyl radical (HOO•) initiated lipid peroxidation. The role of fatty acid hydroperoxides. J Biol Chem 266 : 15091-15098.

Archer SL, Huang J, Henry T, Peterson D, Weir EK (1993) A redoxbased O2 sensor in rat pulmonary vasculature. Circ Res 73: 11001112.

Armstrong D, Sohol RS, Cutler RG, Slater TF (1984) Aging and disease. Free Radic Biol Med 27: 163-180.

Arroyo CM, Kramer JH, Dickens BJ, Weglicki WB (1987) Identification of free radicals in myocardial ischemia/reperfusion by spin trapping with nitrone DMPO. FEBS Lett 221: 101-104.

Aruoma OI, B Halliwell B, Laughton MJ, Quinlan GJ, Gutteridge JM (1989) The mechanism of initiation of lipid peroxidation. Evidence against a requirement for an iron(II)-iron(III) complex. Biochem J 258: 617-620.

Aust SD, Morehouse LA, Thomas CE (1985) Role of metals in oxygen radical reactions. Free Radic Biol Med 1: 3-25.

Bailey DM, Davies B, Young IS, Jackson MJ, Davison GW, Isaacson $\mathrm{R}$, Richardson RS (2003) EPR spectroscopic detection of free radical outflow from an isolated muscle bed in exercising humans. $J$ Appl Physiol 94: 1714-1718.

Bailey DM, Dehnert C, Luks A, Menold E, Castell C, Schendler G, Faoro V, Gutowski M, Evans K, Taudorf S, James P, McEneny J, Young IS, Swenson E, Mairbäurl H, Bärtsch P, Berger MM (2010) High-altitude pulmonary hypertension is associated with a free radical-mediated reduction in pulmonary nitric oxide bioavailability. $J$ Physiol 588: 4837-4847.

Bailey DM, Evans KA, James PE, McEneny J, Young IS, Fall L, Gutowski M, Kewley E, McCord JM, Møller K, Ainslie PN (2009) Altered free radical metabolism in acute mountain sickness: implications for dynamic cerebral autoregulation and blood-brain barrier function. J Physiol 587: 73-85.

Bailey DM, Kleger GR, Holzgraefe M, Ballmer PE, Bärtsch P (2004) Pathophysiological significance of peroxidative stress, neuronal damage, and membrane permeability in acute mountain sickness. $J$ Appl Physiol 96: 1459-1463.

Baldwin DA, Jenny ER, Aisen P (1984) The effect of human serum transferrin and milk lactoferrin on hydroxyl radical formation from superoxide and hydrogen peroxide. J Biol Chem 259: 13391-13394.

Bannister JV, Bellavite P, Davioli A, Thornalley PJ, Rossi F (1982) The generation of hydroxyl radicals following superoxide production by neutrophil NADPH oxidase. FEBS Lett 150: 300-302.

Barb WG, Baxendale JH, George P, Hargrave KR (1951) Reactions of ferrous and ferric ions with hydrogen peroxide. Part I. The ferrous ion reaction. Trans Faraday Soc 97: 462-500.
Barbati S, Bonnefoy A, Botta A, Chiron S (2010) Secondary oxidation of cyclic 1,N2-propano and 1,N2-etheno-2'-deoxyguanosine DNA adducts. Consequences in oxidative stress biomarker development. Chemosphere 80: 1081-1087.

Barja G (1999) Mitochondrial oxygen radical generation and leak: sites of production in states 4 and 3 , organ specificity, and relation to aging and longevity. I Bioenerg Biomembr 31: 347-366.

Bartsch H, Nair J (2006) Chronic inflammation and oxidative stress in the genesis and perpetuation of cancer: role of lipid peroxidation, DNA damage, and repair. Langenbecks Arch Surg 391: 499-510.

Bartz R, Li WH, Venables B, Zehmer JK, Roth MR, Welti R, Anderson RGW, Liu P, Chapman KD (2007) Lipidomics reveals that adiposomes store ether lipids and mediate phospholipid traffic. J Lip Res 48: 837-847.

Bauza G, Lemoyec L, Eugene M (1995) pH regulation during ischaemia-reperfusion of isolated rat hearts, and metabolic effects of 2,3-butanedione monoxime. J Mol Cell Cardiol 27: 1703-1713.

Bendich A, Machlin LJ, Scandurra O, Burton GW, Wayner DM (1986) The antioxidant role of vitamin C. Adv Free Radic Biol Med 2: 419444.

Benton H, Bielski J, Richter HW (1976) A study of superoxide radical chemistry by stopped-flow radiolysis and radiation induced oxygen consumption. I Am Chem Soc 99: 3019-3023.

Bergendi L, Benes L, Durackova Z, Ferencik M (1999) Chemistry, physiology and pathology of free radicals. Life Sci 65: 1865-1874.

Berlett BS, Levine RL, Stadtman ER (1996) Comparison of the effects of ozone on the modification of amino acid residues in glutamine synthetase and bovine serum albumin. J Biol Chem 271: 4177-4182.

Bernier M, Hearse DJ, Manning AS (1986) Reperfusion-induced arrhythmias and oxygen-derived free radicals. Studies with "anti-free radical" interventions and a free radical-generating system in the isolated perfused rat heart. Circ Res 58: 331-340.

Bielski BHJ (1982) Chemistry of Ascorbic Acid Radicals. pp 81-100. American Chemical Society.

Bielski BHJ, Cabelli DE, Arudi RL, Ross AB (1984) Reactivity of hydroperoxyl/superoxide radicals in aqueous solution. J Phys Chem 14: 1041-100.

Bielski BHJ, Richter HW, Chan PC (1975) Some properties of the ascorbate free radical. Ann N Y Acad Sci 258: 231-237.

Bode AM, Cunningham L, Rose RC (1990) Spontaneous decay of oxidized ascorbic acid (dehydro-L-ascorbic acid) evaluated by highpressure liquid chromatography. Clin Chem 36: 1807-1809.

Boh EE, Baricos WH, Bernofsky C, Steele RH (1982) Mitochondrial chemiluminescence elicited by acetaldehyde. J Bioenerg Biomembr 14: 115-133.

Bolli R (1991) Oxygen-derived free radicals and myocardial reperfusion injury. Cardiovasc Drugs Ther 5: 249-268.

Britton RS, Bacon BR, Recknagel RO (1987) Lipid peroxidation and associated hepatic organelle dysfunction in iron overload. Chem Phys Lipids 45: 207-239.

Briviba K, Klotz LO, Sies H (1997) Toxic and signaling effects of photochemically or chemically generated singlet oxygen in biological systems. Biol Chem 378: 1259-1265.

Brodie AE, Reed DJ (1987) Reversible oxidation of glyceraldehydes 3-phosphate dehydrogenase thiols in human lung carcinoma cells by $\mathrm{H}_{2} \mathrm{O}_{2}$. Biochem Biophys Res Commun 148: 120-126.

Bryan NS (2006) Nitrite in nitric oxide biology: cause or consequence? A systems-based review. Free Radic Biol Med 41: 691-701.

Buettner GR (1993) The pecking order of free radicals and antioxidants: Lipid peroxidation, alphatocopherol, and ascorbate. Arch Biochem Biophys 411: 535-43.

Buettner GR, Jurkiewicz BA (1996) Catalytic metals, Ascorbate and Free radicals: Combinations to avoid. Radiat Res 145: 532-541.

Buettner GR, Jurkiewicz BA (1993) Ascorbate free radical as a marker of oxidative stress: an EPR study. Free Radic Biol Med 14: 49-55.

Burkitt MJ, Mason RP (1991) Direct evidence for in vivo hydroxyl-radical generation in experimental iron overload: an ESR spin-trapping investigation. Proc Natl Acad Sci USA 88: 8440-8444.

Cabelli DE, Bielski BHJ (1983) Kinetics and Mechanisms for the Oxidation of Ascorbic Acid/Ascorbate by HO2/O2- Radicals. A Pulse Radiolysis and Stopped-Flow Photolysis Study. J Phys Chem 87: 1809-1812.

Cadenas E, Sies H (1998) The lag phase. Free Radic Res 28: 601-609.

Cadet J, Bellon S, Berger M, Bourdat AG, Douki T, Duarte V, Frelon S, Gasparutto D, Muller E, Ravanat JL, Sauvaigo S (2002) Recent aspects of oxidative DNA damage: Guanine lesions, measurement and substrate specificity of DNA repair glycosylases. $J$ Biol Chem 383: 933-943.

Canning BJ, Reynolds SM, Mazzone SB (2001) Multiple mechanisms of reflex bronchospasm in guinea pigs. J Appl Physiol 91: 2642-2653.

Cao W, Carney JM, Duchon A, Floyd RA, Chevion M (1988) Oxygen free radical involvement in ischemia and reperfusion injury to brain. Neurosci Lett 88: 233-238.

Casimir CA (2006) Handbook of functional lipids. CRC Press.

Catani MV, Rossi A, Castanzo A, Sabatini S, Levrero M, Melino G, Avigliano L (2001) Induction of gene expression via activator pro- 
tein-1 in the ascorbate protection against UV-induced damage. Biochem J 356: 77-85.

Chamulitrat W, Mason RP (1989) Lipid peroxyl radical intermediates in the peroxidation of polyunsaturated fatty acids by lipoxygenase. Direct electron spin resonance investigations. I Biol Chem 264: 20968-20973.

Chatterjee IB (1970) Biosynthesis of L-ascorbate in animals. Methods Enzymol 18: 28-34.

Chevion M (1988) A site-specific mechanism for free radical induced biological damage: the essential role of redox-active transition metals. Free Radic Biol Med 5: 27-37.

Cherry JP, Gray MS, Jones LA (2007) A review of lecithin chemistry and glandless cottonseed as a potential commercial source. J Am Oil Chem Soc 58: 903-913.

Chiueth CC (1999) Neuroprotective properties of nitric oxide. Ann NY Acad Sci 890: 301-311.

Chou PT, Khan AU (1983) L-ascorbic acid quenching of singlet delta molecular oxygen in aqueous media: generalized antioxidant property of vitamin C. Biochem Biophys Res Commun 115: 932-927.

Chu YF, Liu RH (2004) Novel Low-Density Lipoprotein (LDL) Oxidation Model: Antioxidant Capacity for the Inhibition of LDL Oxidation. I Agric Food Chem 52: 6818-6823.

Coassin M, Tomasi A, Vannini V, Ursini F (1991) Enzymatic recycling of oxidized ascorbate in pig heart: oneelectron $v$ s twoelectron pathway. Arch Biochem Biophys 290: 458-462.

Cracowski JL, Durand T, Bessard G (2002) Isoprostanes as a biomarker of lipid peroxidation in humans: physiology, pharmacology and clinical implications. Trends Pharmacol Sci 23: 360-366.

Cuzzocrea S, Riley DP, Caputi AP, Salvemini D (2001) Antioxidant therapy: A new pharmacological approach in shock, inflammation and ischaemia/reperfusion injury. Pharmacol Rev 53: 135-159.

Czapski G, Goldstein S (1995) The role of the reactions of $\bullet \mathrm{NO}$ with superoxide and oxygen in biological systems: a kinetic approach. Free Radic Biol Med 19: 785-794.

Dalle-Donne I, Rossi R, Colombo R, Giustarini D, Milzani A (2006) Biomarkers of oxidative damage in human disease. Clin Chem 52: 601-623.

Darsley-Usmar V, Wiseman H, Halliwell B (1995) Nitric oxide and oxygen radicals: a question of balance. FEBS Lett 369: 131-135.

Davies MJ, Fu S, Wang H, Dean RT (1999) Stable markers of oxidant damage to proteins and their application in study of human disease. Free Radic Biol Med 27: 1151-1161.

Dawson J, Quinn T, Harrow C, Lees KR, Weir CJ, Cleland SJ, Walters MR (2009) Allopurinol and nitric oxide activity in the cerebral circulation of those with diabetes: a randomized trial. Diabetes Care 32: $135-137$.

Dean RT, Fu S, Stocker R, Davies MJ (1997) Biochemistry and pathology of radical-mediated protein oxidation. Biochem J 324: 1-18.

Dietschy JM (1998) Dietary Fatty Acids and the Regulation of Plasma Low Density Lipoprotein Cholesterol Concentrations. J Nutr 128: $444-448$.

Drake BB, Smythe CV, King CG (1942) Complexes of dehydroascorbic acid with three sulfhydryl compounds. I Biol Chem 143: 89-98.

Falchetti ML, Levi A, Molinari P, Verna R,D'Ambrosio E (1998) Increased sensitivity and reproducibility of TRAP assay by avoiding direct primers interaction. Nucleic Acids Res 126: 862-863.

Fessenden RW, Verma NC (1978) A time-resolved electron spin resonance study of the oxidation of ascorbic acid by hydroxyl radical. $J$ Biophys 24: 93-101.

Foote CS, Valentine JS, Greenberg A, Liebman JF (1995) Active Oxygen in Chemistry (Structure, Energetics and Reactivity in Chemistry) Search Series. Volume 2.

Ford PC (2004) Probing fundamental mechanisms of nitric oxide reactions with metal centers. Pure Appl Chem 76: 335-350.

Frei B, England L, Ames BN (1989) Ascorbate is an outstanding antioxidant in human blood plasma. Proc Natl Acad Sci USA 86: 63776381.

Frei B, Gazianot JM (1993) Content of antioxidants, preformed lipid hydroperoxides, and cholesterol as predictors of the susceptibility of human LDL to metal ion-dependent and independent oxidation. $J$ Lipid Res 34: 2135-2145.

Frei B, Stocker R, Amest BN (1988) Antioxidant defenses and lipid peroxidation in human blood plasma. Proc Natl Acad Sci USA 85: 9748-9752.

Frelon S, Douki T, Favier A, Cadet J (2003) Hydroxyl radical is not the main reactive species involved in the degradation of DNA bases by copper in the presence of hydrogen peroxide. Chem Res Toxicol 16: 191-197.

Garlick PB, Davies MJ, Hearse DJ, Slater TF (1987) Direct detection of free radicals in the reperfused rat heart using electron spin resonance spectroscopy. Circ Res 61: 757-760.

Gershman R, Gilbert DL, Nye SW, Dwyer P, Fenn WO (1954) Oxygen poisoning and x-irradiation. A mechanism in common. Science 119: 623-626.

Ghafourifar P, Cadenas E (2005) Mitochondrial nitric oxide synthase. Trends Pharmacol Sci 26: 190-195.
Girotti AW (1998) Lipid hydroperoxide generation, turnover, and effector action in biological systems. J Lipid Res 39: 1529-1542.

Goebel KM, Schneider J (1981) Erythrocyte membrane fluidity, lipid peroxidation and lysis in alcoholic liver disease. Acta Biol Med Ger 40: $571-576$

Goldstein S, Czapski G, Lind J, Merenyi G (1998) Mechanism of decomposition of peroxynitric ion $(\mathrm{O}(2) \mathrm{NOO}(-))$ : evidence for the formation of $\mathrm{O}_{2}{ }^{\circ}$ and $\mathrm{NO}_{2}{ }^{*}$ radicals. Inorg Chem 37: 3943-3947.

Goldstein S, Lind J, Merenyi G (2004) Reaction of organic peroxyl radicals with $\left(\mathrm{NO}_{2}\right)-\mathrm{N}$ - and $(\mathrm{NO})-\mathrm{N}$ - in aqueous solution: Intermediacy of organic peroxynitrate and peroxynitrite species. J Phys Chem 108: 1719-1725.

Gow AJ, Buerk DG, Ischiropoulos H (1997) A novel reaction mechanism for the formation of S-nitrosothiol in vivo. I Biol Chem 272: 2841-2845.

Gow AJ, Chen Q, Gole M, Themistocleous M, Lee VM, Ischiropoulos $\mathrm{H}$ (2000) Two distinct mechanisms of nitric oxide-mediated neuronal cell death show thiol dependency. Am J Physiol Cell Physiol 278: 1099-107.

Gower J, Healing G, Green C (1989) Measurement by HPLC of desferrioxamine-available iron in rabbit kidneys to assess the effect of ischemia on the distribution of iron within the total pool. Free Radic Res Commun 5: 291-299.

Guaiquil VH, Farber CM, Golde DW, Vera JC (1997) Efficient transport and accumulation of vitamin C in HL-60 cells depleted of glutathione. J Biol Chem 272: 9915-9921.

Gutteridge JMC (1986) Iron promoters of the Fenton reaction and lipid peroxidation can be released from haemoglobin by peroxides. FEBS Lett 201: 291.

Gutteridge JMC (1995) Lipid peroxidation and antioxidants as biomarkers of tissue damage. Clin Chem 41: 1819-1828.

Haber F, Weiss J (1932) On the catalysis of hydroperoxide. Naturwissenschaften 20: 948-950.

Haber F, Weiss J (1934) The catalytic decomposition of hydrogen peroxide by iron salts. Proceedings of The Royal Society A: Mathematical, Physical and Engineering Sciences 134: 332-351.

Hakim TS, Sugimori K, Camporesi EM, Anderson G (1996) Half-life of nitric oxide in aqueous solutions with and without haemoglobin. Physiol Meas 17: 267-277.

Halliwell B (1982) Superoxide-dependent formation of hydroxyl radicals in the presence of iron salts is a feasible source of hydroxyl radicals in vivo. Biochem $J$ 205: 461-463.

Halliwell B (1999) Oxygen and nitrogen are pro-carcinogens. Damage to DNA by reactive oxygen, chlorine and nitrogen species: measurement, mechanism and the effects of nutrition. Mutat Res 443: 37-52.

Halliwell B (2001) Role of free radicals in the neurodegenerative diseases: therapeutic implications for antioxidant treatment. Drugs Aging 18: $685-716$.

Halliwell B (2006) Reactive species and antioxidants. Redox biology is a fundamental theme of aerobic Life. Plant Physiology 141: 312-322.

Halliwell, B, Gutteridge JMC (1984) Oxygen toxicity, oxygen radicals, transition metals and disease. Biochem J 219: 1-14.

Halliwell B, Gutteridge JMC (1989) Free Radical Biology and Medicine. Oxford, UK: Oxford University Press.

Halliwell B, Gutteridge JMC (2000) Free Radicals in Biology and Medicine. Oxford Science Publications.

Han J, Kim N, Park J, Seog DH, Joo H, Kim E (2002) Opening of mitochondrial ATP-sensitive potassium channels evokes oxygen radical generation in rabbit heart slices. I Biochem 131: 721-727.

Hansford RG, Hogue BA, Mildaziene V (1997) Dependence of H2O2 formation by rat heart mitochondria on substrate availability and donor age. J Bioenerg Biomembr 29: 89-95.

Harel S, Salan MA, Kanner J (1988) Iron release from metmyoglobin, methaemoglobin and cytochrome $c$ by a system generating hydrogen peroxide. Free Radic Res Commun 5: 11-19.

Harman D (1956) Aging-a theory based on free-radical and radiation chemistry. I Gerontol 11: 298-300.

Harris DC, Aisen P (1973) Facilitation of Fe(II) autoxidation by Fe(III) complexing agents. Biochim Biophys Acta 329: 156-158.

Hiramoto K, Ohkawa T, Oikawa N, Kikugawa K (2003) Is nitric oxide (NO) an antioxidant or a prooxidant for lipid peroxidation? Chem Pharm Bull 51: 1046-1050.

Hirota K, Murata M, Sachi Y, Nakamura H, Takeuchi J, Mori K, Yodoi J (1999) Distinct roles of thioredoxin in the cytoplasm and in the nucleus. A two-step mechanism of redox regulation of transcription factor NF-kappa B. J Biol Chem 274: 27891-27897.

Hogg N, Kalyanaraman B, Joseph J, Struck A, Parthasarathy S (1993) Inhibition of low-density lipoprotein oxidation by nitric oxide. Potential role In atherogenesis. FEBS Lett 334: 170-174.

Holt S, Gunderson M, Joyce K, Nayini NR, Eyster GF, Garitano AM, Zonia C, Krause GS, Aust SD, White BC (1986) Myocardial tissue iron delocalization and evidence for lipid peroxidation after two hours of ischemia. Ann Emerg Med 15: 1155-1159.

Hsiai TK, Hwang J, Barr ML, Correa A, Hamilton R, Alavi M, rouhanizadeh M, Cadenas E, Hazen SL (2007) Hemodynamics influences 
vascular peroxynitrite formation. Implication for low-density lipoprotein apo-B-100 nitration. Free Radic Biol Med 42: 519-529.

Huie RE (1994) The reaction kinetics of $\mathrm{NO}_{2}$. Toxicology 89: 193-216.

Huie RE, Padmaja S (1993) The reaction of NO with superoxide. Free Radic Res Commun 18: 195-199.

Hwang ES, Kim GH (2007) Biomarkers of oxidative stress status of DNA, lipids, and proteins in vitro and in vivo cancer research. Toxicology 229: 1-10.

Hynes AJ, Wine PH, Nicovich JM (1988) Kinetics and mechanism of the reaction of hydroxyl with carbon disulfide under atmospheric conditions. I Phys Chem 92: 3846-3852.

Ignarro LJ, Fukuto JM, Griscavage JM, Rogers NE, Byrns RE (1993) Oxidation of nitric oxide in aqueous solution to nitrite but not nitrate: comparison with enzymatically formed nitric oxide from Larginine. Proc Natl Acad Sci USA 90: 8103-8107.

Im J, Kim D, Paik S, Han P (2006) Cycloooxygenase-2-dependent neuronal death proceeds via superoxide anion generation. Free Radic Biol Med 41: 960-972.

Jacobs A (1977) Low molecular weight intracellular iron transport compounds. Blood 50: 433-439.

Jamieson D (1989) Oxygen toxicity and reactive oxygen metabolites in mammals. Free Radic Biol Med 7: 87-108.

Jenner P (2003) Oxidative stress In Parkinson's disease. Ann Neurol 53: 26-36.

Jezowska-Bojczuk M, Szczepanik W, Leśniak W, Ciesiołka J, Wrzesiński J, Bal W (2002) DNA and RNA damage by Cu(II)-amikacin complex. Eur J Biochem 269: 5547-5556.

Kanofsky JR (1989) Bromine derivatives of amino acids as intermediates in the peroxidas-catalyzed formation of singlet $\mathrm{O}_{2}$. Arch Biochem Biophys 274.

Karwatowska-Prokopczuk E, Czarnowska E, Beresewicz A (1992) Iron availability and free radical induced injury in the isolated ischaemic/ reperfused rat heart. Cardiovasc Res 26: 58-66.

Katoh S, Toyama J, Kodama I, Akita T, Abe T (1992) Deferoxamine, an iron chelator, reduces myocardial injury and free radical generation in isolated neonatal rabbit hearts subjected to global ischaemiareperfusion. J Mol Cell Cardiol 24: 1267-1275.

Kehrer JP (1993) Free radicals as mediators of tissue injury and disease. Crit Rev Toxicol 23: 21-48.

Keyer K, Imlay JA (1996) Superoxide accelerates DNA damage by elevating free-iron levels. Proc Natl Acad Sci USA 93: 13635-13640.

Kharitonov VG, Sundquist AR, Sharma VS (1994) Kinetics of nitric oxide autoxidation in aqueous solution. J Biol Chem 269: 5881-5883.

Kissner R, Nauser T, Bugnon P, Lye PG, Koppenol WH (1997) Formation and properties of peroxynitrite as studied by laser flash photolysis, high-pressure stopped-flow technique, and pulse radiolysis. Chem Res Toxicol 10: 1285-1292.

Klaunig JE, Kamendulis LM (2004) The role of oxidative stress in carcinogenesis. Annu Rev Pharmacol Toxicol 44: 239-67.

Knott AB, Bossy-Wetzel E (2009) Nitric oxide in health and disease of the nervous system. Antioxid Redox Signal 11: 541-554.

Koppenol WH (1990) Oxyradical reactions: from bond-dissociation energies to reduction potentials. FEBS Lett 264: 165-167.

Koppenol WH, Butler J (1985) Energetics of interconversion reactions of oxyradicals. Adv Free Radic Biol Med 1: 91-131.

Kovacic P, Pozos RS, Somanathan R, Shangari N, O’Brien PJ (2005) Mechanism of mitochondrial uncouplers, inhibitors, and toxins: Focus on electron transfer, free radicals, and structure-activity relationship. Curr Med Chem 12: 2601-2623.

Krause GS, White BC, Aust SD, Nayini NR, Kumar K (1988) Brain cell death following ischemia and reperfusion: a proposed biochemical sequence. Crit Care Med 16: 714-726.

Krinsky NI (1979) Biological roles of singlet oxygen. In: Wasserman HH; ed. Singlet Oxygen 40: 597-641.

Kwan WP, Voelker BM (2002) Decomposition of hydrogen peroxide and organic compounds in the presence of dissolved iron and ferrihydrite. Environ Sci Technol 36: 1467-1476.

Lentner C (1984) Geigy Scientific Tables, 3: 132.

Levy AS, Chung JC, Kroetsch JT, Rush JW (2009) Nitric oxide and coronary vascular endothelium adaptations in hypertension. $V$ asc Health Risk Manag 5: 1075-1087.

Lewis RS, Deen WM (1994) Kinetics of the reaction of nitric oxide with oxygen in aqueous solutions. Chem Res Toxicol 7: 568-574.

Linton S, Davies MJ, Dean RT (2001) Protein oxidation and ageing. Exp Gerontol 36: 1503-1518.

Liu XP, Miller MJS, Joshi MS, Thomas DD, Lancaster JR (1998) Accelerated reaction of nitric oxide with $\mathrm{O} 2$ within the hydrophobic interior of biological membranes. Proc Natl Acad Sci USA 95: 21752179 .

Lo SK, Janakidevi K, Lai L, Malik AB (1993) Hydrogen peroxide-induced increase in endothelial adhesiveness is dependent on ICAM-1 activation. Am J Physiol 264: L406-L12.

Loeb LA, James EA, Waltersdorph AM, Klebanoff SJ (1988) Mutagenesis by the autoxidation of iron with isolated DNA. Proc Natl Acad Sci USA 85: 3918-3922.
Lumper L, Schneider W, Staudinger H (1967) Untersuchungen zur Kinetik der mikrosomalen NADH: Semidehydroascorbat- Oxydoreduktase. Hoppe-Seyler's Zeitschrift für physiologische Chemie 348: 323-328.

Maree A, Peer G, Schwartz D, Serban I, Blum M, Wollman Y, Cabili S, Iaina A (1994) Role of nitric oxide in glycerol-induced acute renal failure in rats. Nephrol Dial Transplant 9: 78-81.

May JM, Cobb CE, Mendiratta S, Hill KE, Burk RF (1998) Reduction of the ascorbyl free radical to ascorbate by thioredoxin reductase. $J$ Biol Chem 273: 23039-23045.

May JM, Qu ZC, Li X (2001) Requirement for GSH in recycling of ascorbic acid in endothelial cells. Biochem Pharmacol 62: 873-881.

May JM, Qu ZC, Neel DR, Li X (2003) Recycling of vitamin C from its oxidized forms by human endothelial cells. Biochim Bioph Acta 1640: 153-161.

McCord JM (1985) Oxygen derived free radicals in post-ischemic tissue injury. $N$ Eng J Med 312: 159-163.

Mehlhorn RJ (1991) Ascorbate- and dehydroascorbic acid-mediated reduction of free radicals in the human erythrocyte. J Biol Chem 266: 2724-2731.

Meister A (1994) Glutathione-ascorbic acid antioxidant system in animals. I Biol Chem 269: 9397-9400.

Miller DM, Aust SD (1988) Studies of ascorbate-dependent, iron-catalyzed lipid peroxidation. Arch Biochem Biophys 271: 113-119.

Miller DM, Buettner GR, Aust SD (1990) Transition metals as catalysts of " autoxidation" reactions. Free Radic Biol Med 8: 95-108.

Miller ER, Erlinger TP, Sacks FM, Svetkey LP, Charleston J, Lin PH, Appel LJ (2005) A dietary pattern that lowers oxidative stress increases antibodies to oxidized LDL: results from a randomized controlled feeding study. Atherosclerosis 183: 175-182.

Mittal CK, Murad F (1977) Activation of guanylate cyclise by superoxide-dismutase and hydroxyl radical. Physiological regulator of guanosine 3',5'-monophosphate formation. Proc Natl Acad Sci USA 74: 4360-4364.

Montuschi P, Barnes PJ, Roberts LJ (2004) Isoprostanes: markers and mediators of oxidative stress. FASEB J 18: 1791-1800.

Muller FL, Liu Y, Abdul-Ghani MA, Lustgarten MS, Bhattacharya A, Jang YC, Van Remmen H (2008) High rates of superoxide production in skeletal-muscle mitochondria respiring on both complex Iand complex II-linked substrates. Biochem J 409: 491-499.

Muller FL, Liu Y, Van Remmen H (2004) Complex III releases superoxide to both sides of the inner mitochondrial membrane. J Biol Chem 279: 49064-49073.

Murphy MP (2009) How mitochondria produce reactive oxygen species. Biochem J 417: 1-13.

Myers ML, Bolli R, Lekich RF, Hartley CJ, Roberts R (1985) Enhancement of recovery of myocardial function by oxygen free radical scavengers after reversible regional ischemia. Circulation 72: 915-921.

Myers ML, Bolli R, Lekich RF, Hartley CJ, Roberts R (1986) N-2-mercaptopropionylglycine improves recovery of myocardial function following reversible regional ischemia. J Am Coll Cardiol 8: 1161-1168.

Nagy P, Kettle AJ, Winterbourn CC (2009) Superoxide-mediated formation of tyrosine hydroperoxides and methionine sulfoxide in peptides through radical addition and intramolecular oxygen transfer. $J$ Biol Chem 284: 14723-14733.

Nanni S, Benvenuti V, Grasselli A, Priolo C, Aiello A, Mattiussi S, Colussi C, Lirangi V, Illi B, D’Eletto M, Cianciulli AM, Gallucci M, De Carli P, Sentinelli S, Mottolese M, Carlini P, Strigari L, Finn S, Mueller E, Arcangeli G, Gaetano C, Capogrossi MC, Donnorso RP, Bacchetti S, Sacchi A, Pontecorvi A, Loda M, Farsetti A (2009) Endothelial NOS, estrogen receptor beta, and HIFs cooperate in the activation of a prognostic transcriptional pattern in aggressive human prostate cancer. J Clin Invest 119: 1093-1108.

Nayni NR, White BC, Aust, SD, Huang RR, Indrieri RJ, Evans AT, Bialek H, Jacobs WA. Komara J (1985) Post resuscitation iron delocalization and malondialdehyde production in the brain following prolonged cardiac arrest. Free Radic Biol Med 1: 111-116.

Niki E (1991) Vitamin C as an antioxidant. World Rev Nutr Diet 64: $1-30$.

Niki E, Yoshida Y, Saito Y, Noguchi N (2005) Lipid peroxidation: Mechanisms, inhibition, and biological effects. Biochem Biophys Res Commun 338: 668-676.

Nishikimi M (1975) Oxidation of ascorbic acid with superoxide anion generated by the xanthinexanthine oxidase system. Biochem Biophys Res Commun 63: 463-468.

O’Donnell VB, Chumley PH, Hogg N, Bloodsworth A, Darley-Usmar VM, Freeman BA (1997) Nitric oxide inhibition of lipid peroxidation: kinetics of reaction with lipid peroxyl radicals and comparison with alpha-tocopherol. Biochemistry 36: 15216-15223.

O'Donnell VB, Freeman BA (2001) Interactions between nitric oxide and lipid oxidation pathways: implications for vascular disease. Circ Res 88: 12-21.

O'Donnell VB, Taylor KB, Parthasarathy S, Kühn H, Koesling D, Friebe A, Bloodsworth A, Darley-Usmar VM, Freeman BA (1999) 15-Lipoxygenase catalytically consumes nitric oxide and impairs activation of guanylate cyclase. J Biol Chem 274: 20083-20091. 
Ono S, Westcott JY, Chang SW, Voelkel NF (1993) Endotoxin priming followed by high altitude causes pulmonary edema in rats. $J$ Appl Physiol 74: 1534-1542.

Parker JG, Stanbro WD (1984) Opitical detemination of the rates of formation and decay of $\mathrm{O}_{2}$ in $\mathrm{H}_{2} \mathrm{O}, \mathrm{D}_{2} \mathrm{O}$ and other solvents. $J$ Photochem 25: 545-547.

Parkins CS, Dennis MF, Stratford MR, Hill SA, Chaplin DJ (1995) Ischemia reperfusion injury in tumors: the role of oxygen radicals and nitric oxide. Cancer Res 55: 6026-6029.

Pastor N, Weinstein H, Jamison E, Brendowitz M (2000) A detailed interpretation of $\mathrm{OH}$ radical footprints in a TBP DNA complex reveals the role of dynamics in the mechanism of sequence-specific binding. J Mol Biol 304: 55-68.

Patcher P, Beckman JS, Liaudet L (2007) Nitric oxide and peroxynitrite in health and disease. Physiol Rev 87: 315-424.

Petrat F, Bramey T, Kirsch M, de Groot H (2005) Initiation of a superoxide-dependent chain oxidation of lactate dehydrogenasebound NADH by oxidants of low and high reactivity. Free Radic Res 39: 1043-1057.

Pietri S, Culcasi M, Stella L, Cozzone PJ (1990) Ascorbyl free radical as a reliable indicator of free-radical-mediated myocardial ischemic and post-ischemic injury. A real-time continuous-flow ESR study. Eur J Biochem 193: 845-854.

Poirier B, Michel O, Bazin R, Bariéty J, Chevalier J, Myara I (2001) Conjugated dienes: a critical trait of lipoprotein oxidizability in renal fibrosis. Nephrol Dial Transplant 16: 1598-1606.

Porter NA (1984) Chemistry of lipid peroxidation. Method Ensym 105: 273-282.

Prutz WA, Monig H, Butler J, Land EJ (1985) Reactions of nitrogen dioxide in aqueous model systems: oxidation of tyrosine units in peptides and proteins. Arch Biochem Biophys 243: 125-134.

Pryor WA (1966) Free Radicals. 1-355. New York: McGraw-Hill.

Pryor WA (1976) Free radical reactions in biology: initiation of lipid autoxidation by ozone and nitrogen dioxide. Environ Health Perspect 16: $180-181$.

Pryor WA, Jin X, Squadrito GL (1994) One- and two-electron oxidations of methionine by peroxynitrite. Proc Natl Acad Sci USA 91: 11173-11177.

Qian Y, Buettner GR (1999) Iron and dioxygen chemistry is an important route to initiation of biologic free radical oxidations: An electron paramagnetic resonance spin trapping study. Free Radic Biol Med 26: 1447-1456.

Riley EM, Wahl S, Perkins DJ, Schofield L (2006) Regulating immunity to malaria. Parasite Immunol 28: 35-49.

Rubbo H, Parthasarathy S, Barnes S, Kirk M, Kalyanaraman B, Freeman BA (1995) Nitric oxide inhibition of lipoxygenase-dependent liposome and low-density lipoprotein oxidation: termination of radical chain propagation reactions and formation of nitrogen-containing oxidized lipid derivatives. Arch Biochem Biophys 324: 15-25.

Rubbo H, Radi R, Trujillo M, Telleri R, Kalyanaraman B, Barnes S, Kirk M, Freeman BA (1994) Nitric oxide regulation of superoxide and peroxynitrite-dependent lipid peroxidation. Formation of novel nitrogencontaining oxidized lipid derivatives. J Biol Chem 269: 26066-26075.

Rudolph V, Freeman BA (2009) Cardiovascular consequences when nitric oxide and lipid signaling converge. Circ Res 105: 511-522.

Salonen JT, Nyyssönen K, Korpela H, Tuomilehto J, Seppänen R, Salonen R (1992) High stored iron levels are associated with excess risk of myocardial infarction in eastern Finnish men. Circulation 86: 803-811.

Samuni A, Aronovitch J, Godinger D, Chevion M, Czapski G (1983) On the cytotoxicity of vitamin $\mathrm{C}$ and metal ions. A site-specific Fenton mechanism. Eur I Biochem 137: 119-124.

Santos FW, Zeni G, Rocha JBT, Weis SN, Fachinetto JM, Favero AM, Nouqeira CW (2005) Diphenyl diselenide reverses cadmium-induced oxidative damage on mice tissues. Chem Biol Interact 151: 159-165.

Savini I, Duflot S, Avigliano L (2000) Dehydroascorbic acid uptake in a human keratinocyte cell line (HaCaT) is glutathione-independent. Biochem J 345: 665-672.

Sayre LM, Smith MA, Perry G (2001) Chemistry and biochemistry of oxidative stress in neurodegenerative disease. Curr Med Chem 8: $721-738$.

Schaller B, Graf R (2004) Cerebral ischemia and reperfusion: the pathophysiologic concept as a basis for clinical therapy. J Cereb Blood Flow Metab 24: 351-371.

Schmut O, Gruber E, el-Shabrawi Y, Faulborn J (1994) Destruction of human tear proteins by ozone. Free Radic Biol Med 17: 165-169.

Schulze H-U, Gallenkamp H, Staudinger H (1970) Untersuchungen zum mikrosomalen NADH-abhängigen Elektronentransport. Physiol Chem 351: 809-817.

Sengpiel B, Preis E, Krieglstein, Prehn JH (1998) NMDAinduced superoxide production and neurotoxicity in cultured rat hippocampus neurons: role of mitochondria. Eur J Neurosc 10: 1903-1910.

Sharma MK, Buettner GR (1993) Interaction of vitamin C and vitamin $\mathrm{E}$ during free radical stress in plasma. An ESR study. Free Radic Biol Med 25: 649-53.
Sharoni Y, DanilenkoM, Dubi N, Ben-Dor A, Levy J (2004) Carotenoids and transcription. Arch Biochem Biophys 430: 89-96.

Shi MM, Godleski JJ, Paulauskis JD (1996) Regulation of macrophage inflammatory protein-1alpha mRNA by oxidative stress. I Biol Chem 271: $5878-5883$.

Sobrevia L, Mann GE (1997) Dysfunction of the endothelial nitric oxide signalling pathway in diabetes and hyperglycaemia. Exp Physiol 82: 423-452.

Squadrito GL, Pryor WA (2002) Biological chemistry of peroxynitrate (O2NOOH/O2NOO-). Free Radic Biol Med 33: 381-381.

Stadtman ER, Berlett BS (1997) Reactive oxygen-mediated protein oxidation in aging and disease. Chem Res Toxicol 10: 485-494.

Stamler JS (1995) S-nitrosothiols and the bioregulatory actions of nitrogen oxides through reactions with thiol groups. Curr Top Microbiol Immunol 196: 19-36.

Stocker R, Keaney JF (2004) Role of oxidative modifications in Atherosclerosis. Physiol Rev 84: 1381-1478.

Stratford MR, Dennis MF, Cochrane R, Parkins CS, Everett SA (1997) The role of nitric oxide in cancer. Improved methods for measurement of nitrite and nitrate by high-performance ion chromatography. I Chromatogr A 770: 151-155.

Strijdom H, Chamane N, Lochner A (2009) Nitric oxide in the cardiovascular system: a simple molecule with complex actions. Cardiovasc J Afr 20: 303-310.

Struck AT, Hogg N, Thomas JP, Kalyanaraman B (1995) Nitric-oxide donor compounds inhibit the toxicity of oxidized low-density-lipoprotein to endothelial-cells. FEBS Lett 361: 291-294.

Svingen BA, Buege JA, O’NeaI FO, Aust SD (1979) The Mechanism of NADPH-dependent Lipid Peroxidation. The propagation of lipid peroxidation. J Biol Chem 254: 5892-5899.

Szabo C (2009) Role of nitrosative stress in the pathogenesis of diabetic vascular dysfunction. Br I Pharmacol 156: 713-727.

Tallman KA, Pratt DA, Porter NA (2001) Kinetic Products of Linoleate Peroxidation: Rapid $\beta$-Fragmentation of Nonconjugated Peroxyls. I Am Chem Soc 123: 11827-11828.

Tappel AL, Dillard CJ (1981) In vivo lipid peroxidation: measurement via exhaled pentane and protection by vitamin E. Fed Proc 40: 174 178.

Thomas CE, Morehouse LA, Aust SD (1985) Ferritin and superoxidedependent lipid peroxidation. J Biol Chem 260: 32753280.

Thomas PD, Poznansky MJ (1990) Lipid peroxidation inactivates rat liver microsomal glycerol-3-phosphate acyl transferase. Effect of iron and copper salts and carbon tetrachloride. J Biol Chem 265: 2684-2691.

Tilg H, Moschen AR (2008) Inflammatory mechanisms in the regulation of insulin resistance. Mol Med 14: 222-231.

Tokiwa H, Sera N, Nakanishi Y, Sagai M (1999) 8-Hydroxyguanosine formed in human lung tissues and the association with diesel exhaust particles . Free Radic Biol Med 27: 1251-1258.

Torfgard KE, Adler J (1994) Mechanisms of action of nitrates. Cardiovasc. Drugs Therapy 8: 701-717.

Traber MG (1994) Determinats of plasma vitamin E concentrations. Free Radic Biol Med 16: 229-231.

Triggaiani M, Granata F, Frattini A, Marone G (2006) Activation of human inflammatory cells by secreted phospholipase A2. Biochim Biophys Acta 1761: 1289-1300.

Valko M, Izakovic M, Mazur M, Rhodes CJ, Telser J (2004) Role of oxygen radicals in DNA damage and cancer incidence. Mol Cell Biochem 266: 37-56.

Valko M, Leibfritz D, Moncol J, Cronin MTD, Mazur M, Telser J (2007) Free radicals and antioxidants in normal physiological functions and human disease. Int J Biochem Cell Biol 39: 44-84.

Valko M, Morris H, Cronin MTD (2005) Metals, toxicity and oxidative stress. Curr Med Chem 12: 1161-1208.

Valko M, Rhodes CJ, Moncol J, Izakovic M, Mazur M (2006) Free radicals, metals and antioxidants in oxidative stress-induced cancer. Chem Biol Interact 160: 1-40.

Vergely C, Maupoil M, Clermont G, Bril A, Rochette L (2003) Identyfication and quantification of free radicals during myocardial ischemia and reperfusion using electron paramagnetic resonance spectroscopy. Arch Biochem Biophys 420: 209-216.

Vergely C, Maupoil M, Clermont G, Bril A, Rochette L (1998) Influence of the severity of myocardial ischemia on the intensity of ascorbyl free radical release and on postischemic recovery during reperfusion. Free Radic Biol Med 24: 470-479.

Voogd A, Sluiter W, Vaneijk HG, Koster JF (1992) Low molecular weight iron and the oxygen paradox in isolated rat hearts. J Clin Invest 90: 2050-2055.

Wade RS, Castro CE (1990) Redox reactivity of iron(III) porphyrins and heme proteins with nitric oxide. Nitrosyl transfer to carbon, oxygen, nitrogen, and sulfur. Chem Res Toxicol 3: 289-291.

Walling C (1975) Fenton's reagent revisited. Acc Chem Res 8: 125-131.

Wang MY, Dhingra K, Hittelman WN, Liehr JG, deAndrade M, Li DH (1996) Lipid peroxidation-induced putative malondialdehydeDNA adducts in human brease tissues. Cancer Epidemiol Biomarkers Prev 5: 705-710. 
Watson BD, Ginsberg MD (1989) Ischemic injury in the brain. Role of oxygen radical-mediated processes. Ann NY Acad Sci 559: 269-281.

Wayland BB, Olson LW (1974) Spectroscopic studies and bonding model for nitric oxide complexes of iron porphyrins. I Am Chem Soc 96: 6037-6041.

Wellburn AR (1994) The relative implications of O3 formation both in the stratosphere and the prophosphere. Proc R Soc Edin 102: 33-35.

White BC, Krause GS, Aust SD, Eyster GE (1985) Postischemic tissue injury by iron-mediated free radical lipid peroxidation. Ann Emerg Med 14: 804-809.

Wilkinson F, Brummer JG (1981) Rate constants for the decay and reactions of the lowest electronically excited singlet state of molecular oxygen in solution. J Phys Chem Ref Data 10: 809-999.

Wink DA, Hanbauer I, Krishna MC, DeGraff W, Gamson J, Mitchell JB (1993) Nitric oxide protects against cellular damage and cytotoxicity from reactive oxygen species. Proc Natl Acad Sci USA 90: 9813-9817.

Winkler BS (1987) In vitro oxidation of ascorbic acid and its prevention by GSH. Biochim Biophys Acta 925: 258-264.

Winkler BS, Orselli SM, Rex TS (1994) The redox couple between glutathione and ascorbic acid; A chemical and physiological perspective. Free Radic Biol Med 17: 333-349.
Young IS, Woodside JV (2001) Antioxidants in health and disease. I Clin Pathol 54: 176-186.

Zastawny TH, Altman SA, Randers-Eichhorn L, Madurawe R, Lumpkin JA, Dizdaroglu M, Rao G (1995) DNA base modifications and membrane damage in cultured mammalian cells treated with iron ions. Free Radic Biol Med 18: 1013-1022.

Zhang DX, Gutterman DD (2007) Mitochondrial reactive oxygen species mediated signalling in endothelial cells. Am J Physiol Heart Cir Physiol 292: 2023-2031.

Zhao YL, Houk KN, Olson LP (2004) Mechanisms of peroxynitrous acid and methyl peroxynitrite, ROONO $(\mathrm{RH}, \mathrm{Me})$, rearrangements: a conformation-dependent homolytic dissociation. I Phys Chem 108: 5864-5871.

Zhu X, Smith MA, Honda K, Aliev G, Moreira PI, Nunomura A, Casadesus G, Harris PL, Siedlak SL, Perry G (2007) Vascular oxidative stress in Alzheimer disease. J Neurol Sci 257: 240-246.

Zweier JL, Flaherty JT, Weisfeldt ML (1987) Direct measurement of free radical generation following reperfusion of ischemic myocardium. Proc Natl Acad Sci USA 84: 1404-1407. 